\title{
On the historical core of V2 in Germanic
}

\section{Eric Fuss}

This paper focuses on the origin of the V2 property in the history of Germanic. Considering data from Gothic and Old English (OE), it is suggested that the historical core of the V2 phenomenon reduces to $\mathrm{V}$-to-C movement that is triggered in operator contexts. Therefore, the historical system shares basic properties with limited V2 in Modern English. It is shown that apparent deviations from this pattern that can be observed in Gothic can be attributed to the influence of Greek word order. Concerning the apparently more elaborate V2 properties of $\mathrm{OE}$, it is claimed that a large part of them in fact do not involve a Spec-head relation, but rather result from linear adjacency between the clause-initial element and a finite verb located in $\mathrm{T}^{0}$. Special attention is paid to the placement of pronominal subjects in OE, which are claimed to occupy SpecTP. This contrasts with a lower position of full subjects due to the absence of an EPP in OE. Finally, the loss of superficial V2 orders in the Middle English period is attributed to the development of an EPP feature in T.

Keywords diachronic syntax, Gothic, EPP, Old English, pronoun placement, V2

Eric Fuss, University of Frankfurt, Institut für deutsche Sprache und Literatur II,

Johann Wolfgang Goethe Universität, Grüneburgplatz 1, 60629 Frankfurt, Germany.

E-mail:fuss@lingua.uni-frankfurt.de

\section{INTRODUCTION}

It is a well-known fact that Modern English displays V-to-C movement only in some very limited contexts, in contrast to all other present day Germanic languages which exhibit this movement operation in all main clauses. These contexts include wh-questions, neg-preposing, yes/no-questions and imperatives (see Green 1980 for a detailed overview):

(1) a. What has Floyd seen?

b. *What Floyd has seen?

c. Never would I do that

d. *Never I would do that

e. Have you seen Floyd?

f. *You have seen Floyd?

g. Play this record!

h. *This record play!

Since Rizzi (1996), the trait of English syntax exemplified in (1a-d) is usually referred to as 'residual V2', suggesting that the V2 properties of Modern English 
represent the residue of a former more elaborate V2 system, which was similar to the 'full V2' grammars of the other present day Germanic languages. However, research into the historical syntax of English has shown that this term is actually misleading, since it can be shown that English has never been a V2 language in the sense of the modern Germanic V2 languages (e.g. Kiparsky 1995; Eythórsson 1995, 1996).

This paper focuses on the properties of V2 and V-to-C movement in Early Germanic, building on ideas by Kiparsky (1995) and Eythórsson (1995, 1996). Considering data from Gothic and Old English (OE), further arguments are put forward for the claim that the historical core of the V2 phenomenon reduces to V-to$\mathrm{C}$ movement that is triggered in operator contexts. Therefore, the historical system shares basic properties with the limited V2 properties of Modern English illustrated in (1). It is further shown that Gothic exhibits a set of apparent deviations from this generalization that consist of orders where a clause-initial wh-phrase is not followed by the finite verb, but rather by pronouns or second position particles. Concerning these problematic cases, it is argued that they are actually a result of the fact that the Gothic bible is a translation from Greek that often merely imitates the word order patterns of the Greek original. In other words, it is shown that the apparent counter-examples represent no genuine properties of Gothic syntax, but rather reflect word order properties of New Testament Greek. Concerning OE, it is claimed that its apparently more elaborate V2 properties mostly derive from a frequent pattern that does not involve a Spec-head relation in the CP, but rather results from (accidental) linear adjacency between a fronted topic and the finite verb which is located in $\mathrm{T}^{0}$. Therefore, V2 in OE reduces to a set of 'core cases' where this pattern is derived by a Spec-head configuration between a fronted operator and the finite verb (cf. e.g. Pintzuk 1999), which is again reminiscent of the limited V2 properties of Modern English, revealing a historical continuity from the oldest records to Modern English.

The paper is organized as follows. Section 2 deals with the status of V2 and V-to$\mathrm{C}$ movement in Gothic. Section 3 gives an overview of the basic empirical facts that are relevant for the theoretical analysis of the $\mathrm{V} 2$ properties of $\mathrm{OE}$ which is presented in section 4. Here, special attention is paid to the placement of pronominal subjects in OE, which are claimed to move overtly to SpecTP. This contrasts with a lower position of full subjects which is attributed to the lack of an EPP in OE. Section 5 then discusses the apparent loss of V2 patterns in the Middle English period and attributes this development to the rise of an EPP feature in T. Section 6 summarizes the paper.

\section{V-TO-C IN GOTHIC}

Traditionally, the V2 phenomenon is considered to be an innovation which is associated with the Germanic branch of the Indo-European language family (the older Indo-European languages such as Sanskrit, Old Greek or Latin show no systematic 
V2 patterns), cf. Brugmann \& Delbrück (1900), Kiparsky (1995). Except for a few runic inscriptions, the earliest Germanic data handed down to us is of Gothic origin, dating from the fourth century. Mainly, the texts are quite literal (i.e. word-for-word) translations of a Greek bible. Therefore, the word order of the Gothic bible often merely imitates that of the Greek original. However, Eythórsson $(1995,1996)$ and Ferraresi (1997) convincingly argue that there are systematic deviations from the word order found in the original that can be taken to reveal some central properties of the syntax of Gothic. More specifically, it can be shown that Gothic exhibits systematic verb movement in contexts similar to those that trigger $\mathrm{V}$-to-C movement in present day English (see above). However, before we turn to the relevant evidence, let's review some basic properties of Gothic syntax.

It is a well-known claim (going back to traditional grammarians such as Brugmann \& Delbrück 1900, Behaghel 1932) that the older Germanic languages were characterized by a basic OV order. The same goes for Gothic (cf. Brugmann \& Delbrück 1900, Braune \& Ebbinghaus 1981). However, since the word order of the Gothic bible is profoundly influenced by the word order of the Greek original, only Gothic examples that show OV order independently of the word order of the Greek text constitute clear evidence in favor of a basic OV syntax. Relevant evidence in favor of an OV base comes from cases where a single Greek verb is represented by a verb together with a (non-pronominal) complement in the Gothic translation. Here, the complement usually precedes the verb (cf. Eythórsson 1995, 1996):
a. dwala gatawida foolish made
Gk. emōranen 'made foolish'
b. lofam
palm-PL.DAT
slohun

(1Cor. 1,20; Eythórsson 1996:109)

Gk. errapisan

'(they) smote (him) with the palm of (their) hands'

(Mt. 26,67; Eythórsson 1995:20)

Furthermore, OV order is also dominant when a Greek complex NP is rendered by a relative clause in Gothic:

$\begin{array}{llll}\text { (3) bo boei leikis } & \text { sind } \\ \text { those which of-the-body are }\end{array}$

Gk. ta tēs sarkos

'the things of the flesh'

(Rom. 8,5; Eythórsson 1996:109)

Now, it can be shown that in a number of contexts, the finite verb systematically undergoes movement from its supposed base position into the left clausal periphery 
(cf. Longobardi 1994; Eythórsson 1995, 1996; Ferraresi 1997). Interestingly, these instances of regular V-to-C movement seem to be limited to contexts that license the same movement operation in Modern English: wh-questions, neg-preposing and imperatives. Note that in examples (4)-(6), the position of the finite verb in the Gothic sentence has no model in the Greek original and can therefore be taken to reflect genuine properties of the syntax of Gothic (cf. Eythórsson 1995:22ff.). In (4), the position of the finite verb in the Gothic translation differs from the position occupied by the corresponding verb in the Greek sentence: whereas the finite verb appears in clause-final position in the Greek sentence, it takes the second position in the corresponding Gothic wh-question. This is reminiscent of the V2 order that characterizes $w h$-questions of present day English, cf. (1a). In the Gothic examples in (5) and (6), a combination of verb+complement renders a single Greek verb. However, in contrast to the examples in (2), the verb precedes its complement in imperatives and examples with clause-initial negation. Again, this suggests that the finite verb has undergone a movement operation that targets a functional head in the left clausal periphery, similar to the relevant cases in Modern English cf. (1c) and $(1 \mathrm{~g})$.

(4) ha skuli bata barn wairpan?

what shall that child become

Gk. ti ara paidion touto estai

'what shall that child become?' $\quad$ (Lk. 1,66; Eythórsson 1996:110)

(5) ni nimip arbi

NEG takes inheritance

Gk. mē klēronomēsēi

'shall not be heir'

(Gal. 4,30; Eythórsson 1996:110)

(6) wairp hrains

become clean

Gk. katharisthēti

'become clean!'

(Mt. 8,3, Mk. 1,42, Lk. 5,13; Eythórsson 1996:110)

To sum up, it seems that Gothic already exhibited a form of V-to-C movement that shows some similarities to the 'residual' V2 phenomenon of present day English (at least with respect to the syntactic contexts where this operation is triggered). There is, however, a set of examples that apparently run counter the claim that verb movement is systematically triggered in $w h$-questions. These problematic cases are discussed in the next section.

\subsection{Pronoun placement in wh-questions}

There are some apparent counter-examples to the claim that $w h$-questions involve systematic V-to-C movement in Gothic. First, an apparent violation of the 'V2 
constraint' seems to arise in connection with pronouns that have moved into the left periphery. In wh-questions, subject pronouns can precede, (7), or follow, (8), the finite verb in Gothic, conflicting with the claim that wh-questions always involve V-to-C movement.

$\begin{array}{llllll}\text { a. duhe } & \text { jus } & \text { mitop ubila in hairtam izwaraim? } \\ \text { why you-PL } & \text { think evil in hearts your }\end{array}$

Gk. hinati humeis enthumeisthe ponēra en tais kardiais humōn why you-PL think evil in the heart your

'Why do you think evil in your hearts?' (Mt. 9,4; Ferraresi 1997:53)

b. haiwa bu qipis patei frijai wairpip?

how you-SG say that free become

Gk. pōs su legeis hoti eleutheroi genēsesthe

how you-SG say that free become

'How do you say you shall become free?' (Jo. 8,33; Ferraresi 1997:53)

(8)

$\begin{array}{rllll}\text { a. Wa panamais } & \text { paúrbum } & \text { weis } & \text { weitwode? } \\ & \text { what further } & \text { need } & \text { we } & \text { witness } \\ \text { Gk. } & \text { ti eti } & \text { chreian } & \text { echomen } & \text { marturōn } \\ & \text { what further need } & \text { have-1PL } & \text { witness } \\ & \text { 'What dowe need any further witnesses?' }\end{array}$

'What do we need any further witnesses?' (Mk. 14,63; Ferraresi 1997:55)
b. ha nuk-kant bu, quino?
what now-know you wife

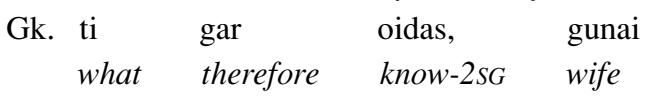

'What do you know, wife?'

(I Cor. 7,16; Ferraresi 1997:55)

However, a closer look reveals the fact that in (7), the Gothic word order is identical with the Greek original, suggesting that these apparent counter-examples are just very literal translations which do not tell us anything about the syntax of Gothic. Interestingly enough, the Gothic examples showing V2 order in (8) correspond to Greek clauses lacking an overt subject. According to Ferraresi (1997:58), there are ten examples where a null subject in the Greek original is rendered by an overt pronoun in the corresponding Gothic main clause. ${ }^{1}$ In eight of these cases, the newly inserted pronoun is located in clause-initial position. The remaining two instances are represented by the $w h$-questions in (8), where the added pronoun resides in postverbal position. Therefore, from the evidence available to us, we can conclude that the newly introduced overt subject pronoun can be taken to indicate some real word order properties of Gothic, namely that pronouns originally had to follow the finite verb in $w h$-questions. In other words, the alleged counter-examples actually support the claim made above, namely that $w h$-questions already exhibit systematic V2 in Gothic. 


\subsection{Wh-questions and second position particles}

Another set of problematic cases has to do with clitic particles that are located in the $\mathrm{C}$ domain. Here, verb movement to second position seems to be blocked in the presence of C-oriented particles which usually also appear in the second position of a clause such as the coordinating particle $-u h$ (+ modality particle pan) as in (9) or a number of modality particles as illustrated in $(10){ }^{2}$

$\begin{array}{lllllll}\text { wan-uh } & \text { ban } & \text { buk } & \text { sehum } & \text { gast } & \text { jah } & \text { ga-lapodedum? } \\ \text { when-PRT } & \text { PRT } & \text { you } & \text { we-saw } & \text { stranger } & \text { and } & \text { PERF-we-invited }\end{array}$

Gk. pote de se eidomen xenon kai sunēgagomen

'And when did we see you as a stranger and invited you?' (Mt. 25,38; TITUS)
a. ha
nu taujai im
frauja
pis
weinagardis?
what PRT do them
owner of-the
vineyard

Gk. ti oun poiēsei autois ho kurios tou ampelōnos

'What then shall the owner of the vineyard do to them?'

(Lk. 20,15; TITUS)

b. ha auk boteip mannan, jabai gageigaip pana fairhu allana what PRT profit man if gain-3SG the-DEM world whole jah gasleipeip sik saiwalai seinai

and injure REFL soul his

Gk. ti gar ōphelei anthrōpon kerdēsai ton kosmon holon kai zēmiōthēnai tēn psuchēn autou

'For what does it profit a man, if he gains the whole world, and loses (lit. injures) his own soul?

(Mk. 8,36; TITUS)

Before we discuss a possible solution for these problematic examples, let's take a closer look at the syntax of these particles. Gothic exhibits a series of particles that are located in the left periphery of the clause and usually appear after the first word (or phrase) of a given clause. These forms include the coordinating particle - $u$, the interrogative particle $-u$, and the modality (or emphatic) particles ban, $n u$ and auk. Traditionally, the placement of these second position particles is taken to follow from Wackernagel's Law (cf. Wackernagel 1892). Furthermore, it can be shown that these particles are connected to sentential properties such as clause type, focus and the main/embedded distinction. In recent generative work on Gothic, it is therefore generally assumed that these particles are generated in the $\mathrm{C}$ domain. If the particle in question is a clitic, it attaches to the right of lexical material that has moved into the left clausal periphery (see Eythórsson 1995, 1996; Ferraresi 1997 for comprehensive discussion).

However, it can be shown that, similar to other word order properties of Gothic, the placement of these particles is also heavily influenced by features of the Greek 
original. For example, a closer look at the examples in (9) and (10) reveals that the second position particles found in the Gothic examples correspond directly to second position particles in the Greek text. The following sections discuss in greater detail the use of second position particles in wh-questions. In particular, it is examined to what extent the position of these particles that appear to violate the V2 constraint in wh-questions can be attributed to word order properties of the Greek original.

\subsubsection{The coordinating particle -uh}

The clitic particle - $u$ h is primarily used to conjoin main clauses. ${ }^{3}$ In order to conjoin other kinds of phrases or embedded clauses, the tonic conjunction jah must be used. ${ }^{4}$ There are many examples where - $u$ h attaches to a fronted finite verb (see Eythórsson 1995, 1996; Ferraresi 1997 for details):

$\begin{array}{llllll}\text { jah usstigun in skip, iddjedun-uh ufar marein } & \text { in } \\ \text { and they-entered in ship went-PRT } & \text { over } & \text { sea }\end{array}$
'and they entered into a ship and crossed the sea'

(Jo. 6,17; Eythórsson 1996:117)

The fact that the particle - $u h$ is in complementary distribution with subordinating complementizers such as $e i$ 'that' (cf. Eythórsson 1995:54) shows that it is sensitive to properties usually associated with $\mathrm{C}$ (i.e. the main/embedded distinction). Therefore it is plausible to assume that $-u h$ is generated under $\mathrm{C}$ (or some functional head of a Split-C system).

The following examples show that - uh not only attaches to verbs that have undergone V-to-C movement, but also to other elements moved into the left periphery, leaving the verb in a position further to the right (i.e. in situ or in a functional head position that is lower than C). In (12a), -uh cliticizes to a topicalized noun. Furthermore, the combination noun+- $u h$ is followed by the modality particle ban. (12b) shows that $-u$ h does not attach to the right edge of a topicalized phrase (here a PP), but rather to its head, splitting the constituent into two parts (similar to the Wackernagel clitics found in Serbo-Croatian, cf. Zec \& Inkelas 1990, Schütze 1994, Ćavar \& Wilder 1999). ${ }^{5}$ Thus, the correct generalization seems to be that $-u h$ attaches to a fronted verb or to the leftmost head of a topicalized phrase (cf. Eythórsson 1995, 1996).
a. buht-up ban qiba ${ }^{6}$
conscience-PRT PRT I-say
'I speak of conscience.'

(1Cor. 10,29; Eythórsson 1996:119)
b. [PP uz-uh pamma mela] managai galipun siponje is from-PRT that time many went of-disciples his 'and from that time many of his disciples went' 
According to Ferraresi (1997:107f.), there are 50 examples where the use of $-u$ h has no model in the Greek original, contrasting with 18 cases where - $u$ h is used to translate Greek second position particles such as de. In addition, there are 122 cases where - $u$ h co-occurs with the modality particle pan. Again, this combination is often used to translate Greek second position particles such as $d e$; in only 7 of these cases the use of $-u h+$ ban has no model in the Greek text. Furthermore, according to Eythórsson (1995:102), there are only three examples where -uh attaches to a clause-initial $w h$-word and the finite verb shows up in a position further to the right:
a. huan-uh
pan buk
sehum gast
jah ga-lapodedum?
when-PRT PRT you saw-1PL stranger
and PERF-we-invited

Gk. pote de se eidomen xenon kai sunēgagomen

'And when did we see you as a stranger and invited you?'

(Mt. 25,38; TITUS)
b. han-uh ban buk sehum siukana aippau in karkarai jah when-PRT PRT you saw-1PL sick or in prison and atiddjedum du bus? came-1PL to you

Gk. pote de se eidomen asthenounta è en phulakē kai ēlthomen 'And when did we see you sick, or in prison, and came to you?'

(Mt. 25,39; TITUS)
c. hua-up
ban habais
patei ni
namt?
what-PRT
PRT have- $2 S G$
that not
received

Gk. ti de ekheis ho ouk elabes

'What do you have that you did not receive?'

(1Cor. 4,7; Eythórsson 1995:102)

In $(13 a-c),-u h$ is directly followed by the modality particle ban 'then'. The finite verb in turn follows either ban, as in (13c), or the pronoun buk, as in (13a-b). Notice that these patterns correspond exactly to the word order of the Greek original. Thus it seems that the combination of $-u h+$ pan serves to translate the adversative particle de which occupies the second position in the Greek original. ${ }^{7}$ Therefore, I would suggest that the distribution of the particle $-u h(+$ ban) actually does not provide a counterexample to the claim that $\mathrm{V}$-to-C movement is systematically triggered in Gothic $w h$-questions (see section 2.2.3 for a discussion of modality particles).

\subsubsection{The interrogative particle $-u$}

The interrogative particle $-u$ serves to signal yes/no-questions in main as well as in embedded contexts. Again, it is plausible to assume that this particle is generated in the $\mathrm{C}$ domain since it is directly associated with clausal typing. In most cases, $-u$ cliticizes to a clause-initial verb, as in (14), but there are also examples where $-u$ 
attaches to other elements. Similar to $-u h,-u$ can also cliticize to the head of a topicalized phrase, as in (15).

$\begin{array}{llllll}\text { maguts-u } & \text { driggkan } & \text { stikl } & \text { panei } & \text { ik driggka...? } \\ \text { you-can-DU.-PRT } & \text { drink } & \text { of-the-cup } & \text { that } I & \text { drink }\end{array}$

'can you drink of the cup that I drink of?' (Mk. 10,38; Eythórsson 1996:125)

(15) [PP ab-u pus silbin] bu pata quis pau anparai pus qepun bi mik of-PRT you self you that say or others you told of me 'do you say this thing of yourself or did others tell it of me?'

(Jo. 18,22; Ferraresi 1997:112)

The use of the interrogative particle $-u$ is apparently a genuine trait of Gothic, since 'in all examples where $-u$ appears there is no corresponding particle in Greek' (Ferraresi 1997:112). Therefore, it is plausible to assume that the placement of $-u$ reveals genuine properties of the Gothic grammar. Unfortunately, as noted above, $-u$ exclusively serves to mark (main and embedded) yes/no-questions. Thus, there are no examples where $-u$ attaches to a $w h$-phrase. In other words, there are no examples where the insertion of $-u$ leads to a violation of the V2 constraint in $w h$-questions.

\subsubsection{The modality particles ban, nu and auk}

Another set of elements that regularly take clausal second position in the Gothic bible consists of the particles ban 'then', nu 'now, thus' and auk 'because, also, thus'. According to Ferraresi (1997:112ff.), ban and $n u$ can be used either as adverbials or as modality particles. In the latter use, they are confined to second position where they can be preceded by any other element. No such positional restrictions can be observed if pan and $n u$ function as adverbials. In contrast, auk exclusively serves to render Greek emphatic particles which appear in second position.

The modality particles differ from $-u h$ and, particularly, $-u$ in that their placement is even more dependent on properties of the Greek original. For example, there are 226 examples where the particle pan translates Greek second position particles and only 12 cases where its insertion has no model in the Greek text (Ferraresi 1997:115f.). ${ }^{8}$ The particles $n u$ and $a u k$ are almost exclusively used to render Greek second position clitics: there are only four examples where $n u$ is used as an emphatic second position particle without a model in the Greek text (contrasting with 92 examples where $n u$ translates second position particles of Greek, cf. Ferraresi 1997:118). Finally, as already noted above, there is no example of independent placement of auk, which is used only to translate Greek second position particles (Ferraresi 1997:122).

A search conducted within the TITUS corpus (New Testament (NT) only) produced the following numbers, presented in Table 1, for cases where a clauseinitial $w h$-word is immediately followed by a modality particle (with the finite verb in a position to the right of this complex). ${ }^{9}$ 


\begin{tabular}{lllllc}
\hline & pan & - uh + pan & nu & auk & Total \\
\hline haas (masc.nom) & $(1)^{*}$ & - & - & 2 & 3 \\
\hline ha (neut.nom/acc) & - & 1 & 7 & 5 & 13 \\
\hline hô (fem.nom/acc) & - & - & $1^{* *}$ & - & 1 \\
\hline hê (neut.instr) & - & - & 2 & - & 2 \\
\hline han 'when' & - & 2 & - & - & 2 \\
\hline haiwa 'how' & - & - & 4 & - & 4 \\
\hline hapar 'which of two' & - & - & 1 & - & 1 \\
\hline duhê 'why' & - & - & - & 1 & 1 \\
\hline
\end{tabular}

* See n. 2.

** In an embedded clause introduced by jabai 'if' (Phil. 2,1).

Table 1. Wh-words immediately followed by a modality particle in the Gothic bible (NT).

Crucially, it can be shown that in all instances where insertion of a modality particle leads to an apparent violation of the V2 constraint in wh-questions, the position of the Gothic particle imitates the position of the corresponding element in the Greek text. Table 2 contains a complete line-up of Gothic second position particles occurring in $w h$-questions and their counterparts in the corresponding passage of the Greek original. ${ }^{10}$

\begin{tabular}{lllllllr}
\hline & \multicolumn{4}{l}{ Greek 2nd position particles } & & No corresponding & \\
\cline { 2 - 5 } & de & gar & oun & nun & & Greek particle & Total \\
\hline ban & 1 & - & - & - & 0 & 1 \\
\hline -uh pan & 3 & - & - & - & 0 & 3 \\
\hline nu & 2 & - & 12 & 1 & 0 & 15 \\
\hline auk & - & 8 & - & - & 0 & 8 \\
\hline
\end{tabular}

Table 2. Gothic 2nd position particles in $w h$-questions and corresponding Gk. particles (NT). ${ }^{11}$

Importantly, this comparison reveals that in the Gothic bible, there are no instances where a second position particle that shows up in a given $w h$-question (i.e. violating V2) has no model in the Greek original. Therefore, we can conclude that the placement of Gothic second position particles does not provide a counterexample for the claim that Gothic already exhibited systematic V2 in wh-questions: in all relevant cases, a given Gothic particle merely renders a corresponding second position element of the Greek text. In other words, the examples in (9) and (10), repeated here as (16) and (17), are actually representative of the translation practice in question. 
(16)

$\begin{array}{lllllll}\text { ban-uh } & \text { ban } & \text { buk } & \text { sehum } & \text { gast } & \text { jah } & \text { ga-lapodedum? } \\ \text { when-PRT } & \text { PRT } & \text { you } & \text { we-saw } & \text { stranger } & \text { and } & \text { PREF-we-invited }\end{array}$

Gk. pote de se eidomen xenon kai sunēgagomen

'And when did we see you as a stranger and invited you?' (Mt. 25,38; TITUS)

$\begin{array}{llllll}\text { a. ha } & \text { nu taujai im frauja pis } & \text { weinagardis? } \\ \text { what } & P R T & \text { do them owner of-the vineyard }\end{array}$

Gk. ti oun poiēsei autois ho kurios tou ampelōnos

'What then shall the owner of the vineyard do to them?'

(Lk. 20,15; TITUS)

b. ha auk boteip mannan, jabai gageigaip pana fairhu what PRT profit man if gain-3SG the-DEM world allana jah gasleipeip sik saiwalai seinai whole and injure REFL soul his

Gk. ti gar ōphelei anthrōpon kerdēsai ton kosmon holon kai zēmiōthēnai tēn psuchēn autou

'For what does it profit a man, if he gains the whole world, and loses (lit. injures) his own soul?

(Mk. 8,36; TITUS)

\subsection{Summary}

This section argued (basically following Eythórsson 1995, 1996) that Gothic already exhibited systematic V-to-C movement in a set of syntactic contexts that are quite similar to the contexts that trigger V-to-C movement in present day English, that is, neg-preposing, imperatives and wh-questions. With respect to the latter context, I discussed two sets of alleged counter-examples that arise when the second position in a $w h$-question is not occupied by the finite verb, but rather by pronouns or particles such as $-u h$, ban, nu or auk. Here, it was shown that these apparent violations of V2 can be attributed to the fact that the word order of the Gothic bible often merely imitates the word order of the corresponding Greek passages. A closer study of the use of second position particles in $w h$-questions revealed that all apparent violations of V2 correspond to a similar pattern in the Greek original, that is, there are no instances where a second position particle that shows up in a given $w h$-question has no model in the Greek text. Thus, we reached the conclusion that in these examples, the non-adjacency of the $w h$-phrase and the finite verb results from a literal word-forword translation of the Greek text and therefore does not tell us anything about the word order properties of Gothic. Moreover, concerning the placement of pronouns, it was demonstrated that pronouns that are inserted against the Greek original (i.e. in cases where the corresponding Greek passage does not contain a pronoun) obey the V2 constraint and follow the finite verb in wh-questions. In a nutshell, then, it seems that the evidence available to us provides more indications that the earliest stages of 
Germanic already showed a form of systematic V2 limited to $w h$-questions, whereas apparent counter-examples can be shown to follow from extra-grammatical factors.

\section{V2 IN OLD ENGLISH}

The preceding section argued that in $w h$-questions, V2 was actually more systematic in the earliest Germanic records than a first inspection of the relevant data might suggest. In contrast, this section aims to show that the apparently more elaborate V2 properties of another historical variety of Germanic, Old English (OE), are actually also restricted to cases where $\mathrm{V}$-to-C movement is triggered in operator contexts, which is again reminiscent of the limited V2 properties of Modern English (cf. Pintzuk 1993, 1999; Cardinaletti \& Roberts 1991; Eythórsson 1995 and others).

It is a well-established fact that $\mathrm{OE}$ displays $\mathrm{V} 2$ patterns in non-embedded sentences similar to the modern Germanic languages. This is exemplified below. Finite verbs (main verbs AND auxiliaries) may occur in second position, immediately following clause-initial subjects, as illustrated in (18), objects, as in (19), PPs, in (20), adverbs, in (21), or wh-phrases, in (22). In the contexts (19)-(22), this results in inversion of the subject and the finite verb.

(18) [Se swicola Herodes] cwæð to ðam tungel-witegum. the treacherous Herod spoke to the star-wisemen 'The treacherous Herodes spoke to the astrologers.'

(AHTh, I, 82.15; van Kemenade 1987:17)

(19) [Maran cyððе] habbað englas to God ponne men. more affinity have angels to God than men 'Angels have more affinity to god than men.'

(AHth, I, 10.3; van Kemenade 1987:17)

(20) [On twam pingum] hafde God pæs mannes sawle gegodod. in two things had God the man's soul endowed 'God had endowed man's soul with two things.'

(AHth, I, 20; van Kemenade 1987:18)

(21) And [egeslice] spæc Gregorius be ðam... and sternly spoke Gregorius about that

'And Gregorius spoke sternly about that...'

(Wulfstan, 202.46; Haeberli 2000:1)

(22) [Hwi] wolde God swa lytles pinges him forwyrnan? why would God such small thing him deny 'Why would God deny him such a small thing?'

(AHth, I, 14; van Kemenade 1987:112)

At first sight, these examples seem to indicate that OE should be treated on a par with a present day V2 language such as German. In the following section, 
however, we will see that OE displays word order patterns which are not found in the modern Germanic V2 languages, and thus object to a uniform analysis of OE and these languages.

\subsection{Deviations from V2}

In the literature on $\mathrm{OE}$, it has often been noted that $\mathrm{OE}$ shows a number of deviations from the V2 pattern that is characteristic of the modern Germanic languages. This section deals with two of these cases: first, V3 patterns arise systematically in connection with (subject) pronouns that occupy the second position. Second, it is shown that V3 also occurs quite frequently with full nominal subjects that fail to invert with the finite verb when scene-setting adverbs are fronted to clause-initial position.

\subsubsection{V3 and pronoun placement}

It is a well-known fact that pronouns may intervene between a topicalized phrase and the finite verb in early stages of Germanic (cf. the work of traditional grammarians such as Behaghel 1932 or Fourquet 1938). More recently, this observation has received considerable attention in generative approaches to OE (e.g. van Kemenade 1987, Pintzuk 1999), where it has been shown that pronominal subjects systematically intervene between the finite verb and an initial topicalized XP, giving rise to V3 orders, which are reminiscent of the word order found in Modern English; this is shown in (23). Similar orders can be found with pronominal objects, as illustrated in (24). ${ }^{12}$

a. [Æfter his gebede] he ahof paet cild up
after his prayer he lifted the child up
'after his prayer, he lifted the child up'

(AHth, II, 28; van Kemenade 1987:110)

b. [bas ping] we habbap be him gewritene
these things we have about him written
'these things we have written about him'

(PC, 1087, 143; van Kemenade 1987:110)

$\begin{array}{ccclll}\text { (24) } & \text { Fela } & \text { spella }] & \text { him sædon ba Beormas } \\ \text { many } & \text { stories } & \text { him told the Permians }\end{array}$

'the Permians told him many stories'

(Oros., 14.27; van Kemenade 1987:114)

However, it can be shown that V3 orders in connection with pronouns do not occur freely. Rather, there are systematic constraints that restrict this violation of the V2 rule to certain contexts (cf. van Kemenade 1987, Pintzuk 1999). Here, we can observe that pronominal elements systematically follow the finite verb if the 
clause-initial constituent is a $w h$-phrase, as in (25), a neg-adverb/particle, as in (26), or a temporal adverb such as $b a$ 'then', ponne 'then' or $n u$ 'now', as illustrated in (27)..$^{13}$

$\begin{array}{cllll}{[\mathrm{Hu}]} & \text { begæst } & \text { bu } & \text { weorc } & \text { bin? } \\ \text { how } & \text { go-about } & \text { you } & \text { work } & \text { your }\end{array}$

'how do you go about your work?' (Æcoll. 22; van Kemenade 1987:138f.)

(26) $[\mathrm{Ne}]$ mæge we awritan ne mid wordum asecgan

NEG can we write NEG with words express

ealle ba wundra

all those wonders

'we can neither write nor express with words all those wonders'

(ÆLS 21.242; Kiparsky 1995:147)
a. [ba] ondwyrdon hie him tweolice...
then answered they him doubtingly

'Then they answered him doubtingly ...'

(Orosius 156.2-3; Kiparsky 1995:147)

$\begin{array}{llllll}\text { b. [bonne] } & \text { sceolon } & \text { we } & \text { singallice gemunan } & \text { pone } \\ \text { then } & \text { shall } & \text { we continually } & \text { think } & \text { about-that } \\ \text { egesfullan } & \text { domes } & \text { dæg. } & & & \\ \text { awesome } & \text { dooms } & \text { day } & & & \end{array}$

'Then we shall think continually about that awesome dooms day.'

(Blickling 101; Swan 1994:243)

A summary of the descriptive findings reached so far is given in (28). Note that these statements cover only the distribution of pronominal elements in the left periphery of non-embedded clauses of OE.

(28) Distribution of pronouns in non-embedded sentences of $O E$

a. $\mathrm{XP}-$ pronoun $-\mathrm{V}_{\text {fin }}$

$$
* \mathrm{XP}-\mathrm{V}_{\text {fin }}-\text { pronoun }
$$

b. $\mathrm{WH} / \mathrm{NEG} /$ pa/ponne $-\mathrm{V}_{\text {fin }}-$ pronoun

${ }^{*} \mathrm{WH} / \mathrm{NEG} /$ ba/bonne - pronoun $-\mathrm{V}_{\text {fin }}$

Thus, abstracting away from the examples with temporal adverbs such as $b a$, it seems that V2 is forced when a syntactic operator is fronted to clause-initial position. Interestingly, this is exactly the context that (still) triggers $\mathrm{V}$-to-C movement in Modern English. In other words, concerning the placement of pronominal subjects, there is apparently a continuity from OE to Modern English: fronting of non-operators leads to the order [XP - pronoun - V], whereas V2 is forced by fronted operators. Therefore, it seems that the main difference between OE and Modern English with respect to V2 consists in the loss of the structures illustrated in (19)-(21), that is, subject-verb inversion with full nominal subjects in cases where a non-operator is 
fronted (cf. Haeberli 1999, 2000). ${ }^{14}$ However, even in the latter context, subject-verb inversion is less systematic in OE than in the modern Germanic V2 languages. This is shown in the next section.

\subsubsection{V3 orders with non-pronominal subjects}

Already in $\mathrm{OE}$, there are cases of $\mathrm{V} 3$ orders where the subject is not a pronoun, but rather a full nominal DP that fails to undergo inversion with the finite verb when a non-operator occupies the clause-initial position. According to Kroch \& Taylor (1997:304), this type of V3 order occurs most frequently with temporal adverbs that function as 'scene setters', as in (29).

a. [Æfter beossum wordum] [se Hælend] cwæb to his leornerum... after these words the Savior spoke to his disciples

(Blickling 135; Swan 1994:241)

b. [Her] [Oswald se eadiga arceb] forlet pis lif. in-this-year Oswald the blessed archbishop forsook this life (ASC, Laud (992); Kroch \& Taylor 1997:304)

Swan (1994), Koopman (1998) and Haeberli (1999, 2000) show that this word order pattern is actually quite frequent in the $\mathrm{OE}$ data. Based on a quantitative analysis of ten OE text samples, Haeberli (2000:4) calculates a percentage of $28.7 \%$ for cases where fronting of a non-operator does not lead to inversion of a nominal subject and the finite verb. Note however, that V2 is still the majority pattern (over 70\%) when a non-operator is fronted in OE. ${ }^{15}$

To sum up, this section has shown that OE differs from the present day Germanic V2 languages in that there is a significant number of cases where subject-verb inversion does not take place when a topicalized (non-operator) phrase occupies the clause-initial position. These examples exhibit V3 orders, which are reminiscent of the syntax of Modern English. Moreover, we have seen that OE exhibits another resemblance to Modern English in that V2 is systematically triggered by a fronted operator. Thus, we can conclude that the main difference between the V2 properties of $\mathrm{OE}$ and Modern English consists in the frequent occurrence of V2 orders where the clause-initial position is occupied by a topicalized non-operator element and we can observe inversion of a non-pronominal subject and the finite verb. In contrast, pronominal subjects seem to exhibit the same distribution as in Modern English, that is, they follow the finite verb only in operator contexts. The following sections focus on the theoretical analysis of the V2 properties of OE and the diachronic developments that led to the system found in present day English. 


\section{4. 'PSEUDO V2' IN OLD ENGLISH}

This section develops a theoretical analysis of OE which is based on the wellestablished idea that the finite verb moves up to $\mathrm{C}$ only in operator contexts, whereas it occupies a lower functional head position in all other non-embedded clauses (as first proposed by Cardinaletti \& Roberts 1991 and Susan Pintzuk in her 1991 dissertation, later published as Pintzuk 1999; see below for further references). The upshot, then, is that V2 orders in $\mathrm{OE}$ can result from two different structural configurations: in operator contexts, $\mathrm{V} 2$ is the outcome of a Spec-head configuration that holds between a fronted operator and the finite verb. In addition, superficial V2 orders may follow from a merely linear adjacency between a topicalized phrase (in SpecCP) and the finite verb that moves to the head of TP (which I will call 'pseudo V2'). Moreover, it is argued that V3 orders with pronouns can be accounted for on the assumption that their categorial status allows them to move overtly to SpecTP, in contrast to full nominal subjects. Before turning to the specifics of the proposal, let's briefly review some previous accounts of the V2/V3 orders found in OE.

In the generative literature on the history of English, one can identify two major approaches to the V2 properties exhibited by OE. The first type of analysis (cf. van Kemenade 1987, Tomaselli 1995) treats OE in a way similar to the modern Germanic V2 languages, combined with further assumptions to account for the V3 orders found with pronominal subjects. More specifically, the pronouns of OE are analyzed as clitics that adjoin to the left of the finite verb in non-operator contexts, but to the right of the verb if the clause-initial element is a wh-phrase or a neg-operator (due to an adjacency requirement that holds between the operator and the finite verb). However, apart from the fact that a mechanism where the direction of adjunction is sensitive to the syntactic context seems to be quite ad hoc, this analysis raises a problem from a comparative point of view: given the assumption that $\mathrm{OE}$ and the modern Germanic V2 languages should be analyzed in a completely uniform manner, the absence of $\mathrm{V} 3$ orders in connection with pronouns in the latter ones is unexpected. Moreover, it can be shown that this analysis fails to explain the partial loss of V2 orders in later historical stages of English (cf. Lightfoot 1995 and Haeberli 1999 for discussion).

The second type of analysis is based on the intuition that the placement of pronominal elements and the systematic deviations from V2 should be taken to indicate that there are fundamental differences between $\mathrm{OE}$ and the modern V2 languages (cf. Cardinaletti \& Roberts 1991; Roberts 1993; Eythórsson 1995, 1996; Hulk \& van Kemenade 1995, Roberts 1996; Kroch \& Taylor 1997; Fuss 1998; Haeberli 1999, 2002; van Kemenade 1999; Pintzuk 1999; Fischer et al. 2000). According to this type of analysis, the pronominal subjects of OE occupy a fixed position on the left edge of IP (or the left edge of a split IP). ${ }^{16}$ As a consequence, the V2/V3 orders observed in connection with pronouns are the result of different structural positions of the finite verb. In cases where SpecCP is occupied by an 
operator (e.g. a wh-phrase), the finite verb moves to C. This movement skips the position of the subject pronoun, giving rise to V2 orders in OE where the finite verb and the clause-initial operator are in a Spec-head relationship. In all other matrix clauses, however, the finite verb resides in a lower head position (Pintzuk 1999: $\mathrm{I}^{0}$, Cardinaletti \& Roberts 1991: Agr1 ${ }^{0}$; Haeberli 1999: Agrs ${ }^{0}$; Fuss 1998: $\mathrm{T}^{0}$; Hulk \& van Kemenade 1995, Fischer et al. 2000: $\mathrm{F}^{0}$ ). Therefore, a subject pronoun which is located at the left edge of the (split) IP intervenes between a topic (presumably moved into some specifier of the C-system) and the finite verb, resulting in V3 orders. Finally, cases of subject-verb inversion with full nominal subjects and fronted nonoperators are accounted for by the assumption that non-pronominal subjects can be licensed in a lower specifier position in OE (e.g. SpecVP), that is crossed by verb movement to some inflectional head. In other words, it is claimed that the majority of $\mathrm{V} 2$ orders found in OE result from a configuration where the topic and the finite verb are merely linearly adjacent (there is no Spec-head relation involved). In the remainder of this paper I will call this configuration 'pseudo V2'. The gist of the second type of analysis is schematically illustrated by the pair of phrase markers in (30), making use of the traditional CP-IP-VP model of clause structure.

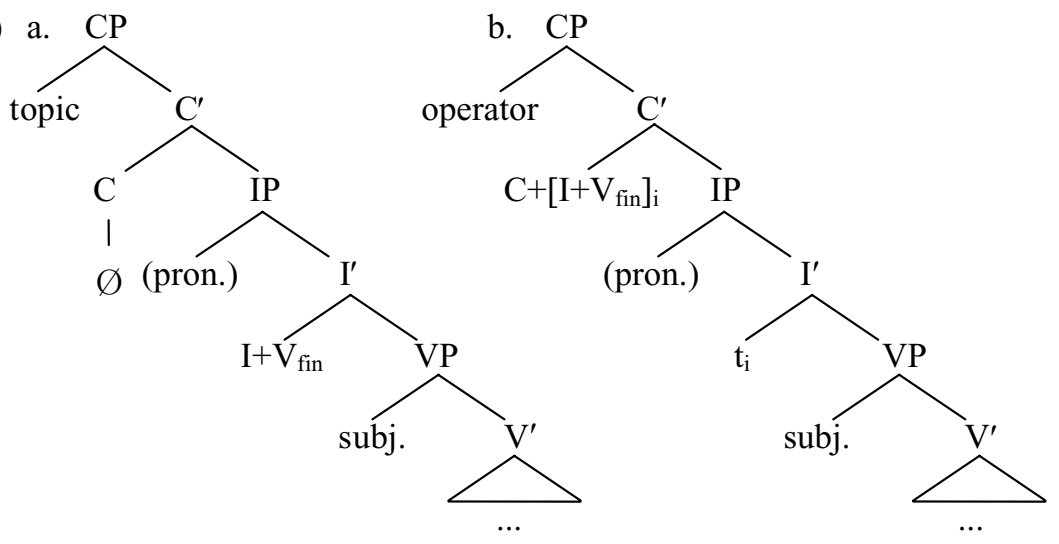

Although this analysis fares better in accounting for the relevant empirical facts than previous approaches, it is rather obvious that it involves a number of (non-standard) assumptions which are by no means self-evident or motivated on independent grounds (apart from the word order facts the analysis is supposed to account for). For example, it is mostly left unclear why pronouns have to move to the left edge of IP whereas non-pronominal subjects prefer to stay in situ (but see e.g. Kroch \& Taylor 1997 and especially Haeberli 1999, 2002 for more detailed suggestions). Similarly, the principles governing verb movement are often only vaguely stated. ${ }^{17}$ This section sets out to develop a version of this approach to OE (illustrated by the phrase markers in (30)), where the relevant theoretical assumptions are laid out more explicitly. The account on hand is based on the 'minimalist' clause 
structure proposed in Fuss (1998), Fuss \& Trips (2002) for OE, where the subject is assumed to receive its theta-role in the specifier of $v \mathrm{P}$, the head of which assigns object case to a second, outer specifier (cf. Chomsky 1995, Kratzer 1996 and others).

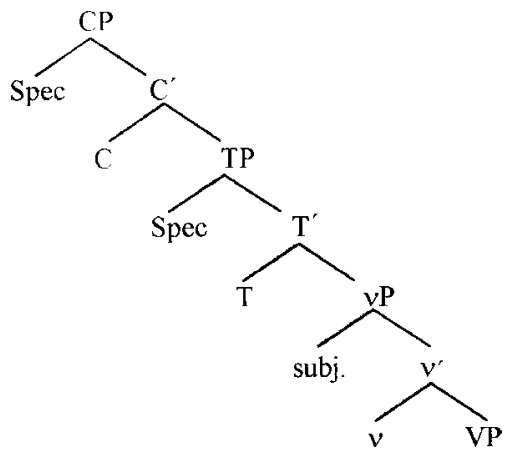

Let's first take a closer look at how the movement operations that give rise to the structures in (30) translate into this model. Concerning the position of the finite verb, I basically follow the analysis proposed in Fuss \& Trips (2002), where it is assumed that movement of the verb to $\mathrm{T}$ in main clauses of $\mathrm{OE}$ is triggered by requirements on the licensing of Tense. Further movement up to $\mathrm{C}$ is not necessary to satisfy this requirement and is therefore ruled out by economy (Last Resort, Chomsky 1995) if C does not contain operator features, see below (cf. Travis 1984, Bennis \& Hoekstra 1989; see Roberts \& Roussou 2001 and Pesetsky \& Torrego 2000 for more recent implementations of similar ideas). In embedded clauses, these requirements are met by insertion of a complementizer, blocking verb movement. ${ }^{18}$ In operator contexts (i.e. (30b)), the finite verb moves further up to $\mathrm{C}$ (or some head of a split $\mathrm{CP}$ ), presumably attracted by criterial features (i.e. some form of the $W h$-criterion, cf. May 1985, Rizzi 1996). By common assumptions, operators move into the $\mathrm{C}$ domain for reasons of scope.

Next, let's address the structural position of topics in OE (i.e. fronted nonoperators). According to Fischer et al. (2000) topicalization in OE should be analyzed as movement to SpecCP, since it is a phenomenon confined to root clauses. Movement of topics into the $\mathrm{C}$ domain can be motivated on the assumption that the $\mathrm{C}$ domain of non-embedded clauses functions as the interface between the propositional content of a clause (represented by the Infl/T domain) and the discourse context (cf. Rizzi 1997, Grewendorf 2002). Accordingly, elements have to move into the C-system in order to receive an interpretation as topics in a given discourse context. Alternatively, one might assume that this movement is triggered by an optional 'EPP'-feature located in the attracting functional head, if one wants to stick to the idea that syntactic movement operations must be feature-driven (cf. Chomsky 2000).

Let's now turn to the question of how we can motivate the different positions of pronominal and non-pronominal subjects in OE. Above, it has been claimed that we 
can explain $\mathrm{V} 3$ orders in connection with pronouns on the assumption that they occupy a higher position than nominal subjects which are licensed in a lower, presumably VP-internal position. Let's first take a closer look at the structural position of nominal subjects in OE (cf. van Kemenade 1997, Kroch \& Taylor 1997, Haeberli 1999, Pintzuk 1999, Fischer et al. 2000 for relevant arguments and discussion). Relevant arguments for the assumption that non-pronominal subjects can reside in a VP-internal position comes from passives where a (definite) nominative DP follows the passive participle (Haeberli 1999:370), cf.

by ilcan geare wæs gecoren [Æpelheard abbud] to biscepe.
the same year was chosen Ae. abbot to bishop

'In the same year, the abbot Aethelhard was chosen as bishop.'

(ChronA, 54.790.1; Haeberli 1999:370)

Furthermore, Fischer et al. (2000:124f.) note a very interesting distributional difference between nominal and pronominal subjects which provides further support for the assumption that nominal subjects are licensed in a lower, presumably VPinternal position: In examples with multiple sentential negation (consisting of the clitic ne and the negative adverb $n a$ ) pronominal subjects appear to the left of $n a$ whereas nominal subjects consistently follow na:

a. Ne het he us na leornian heofonas to wyrcenne.
not ordered he us not learn heavens to make

'He did not bid us learn to make the heavens.'

(ÆLS, 127; Fischer et al. 2000:125)

b. Nis na se halga gast wuniende on his gecynde not-is not the holy ghost existing in his nature swa swa he gesewen wæs. as he seen was

'The Holy Ghost is not existing in his nature as he was seen.'

(ÆCHom I, 22.322.17; Fischer et al. 2000:125)

Under standard assumptions concerning the structural positions of negative adverbs such as $n a$ - either located in SpecNegP or adjoined to VP - these examples suggest that nominal subjects can remain in their base position where they receive their theta-role. In the syntactic model on hand, this position is identified as the specifier of $\nu \mathrm{P}$ (for the external argument of transitive and unergative verbs). ${ }^{19} \mathrm{In}$ contrast, it seems that pronominal subjects can (or must) move to a position on the left edge of IP (or rather TP in the analysis proposed in this paper). Therefore, I conclude that nominal subjects are licensed in their base position in OE. In other words, in contrast to Modern English, there is no obligatory movement of full nominal subject DPs to SpecTP. This can be implemented in a more formal way by the assumption that $\mathrm{T}$ does not host an EPP-feature in OE. As a consequence, it's only the syntactically 
relevant features of nominal subjects (i.e. $\mathrm{D}$, case, $\varphi$ ) that move to $\mathrm{T}$, whereas the phonological features remain in a lower position $(\operatorname{Spec} v \mathrm{P})$ where they are spelled out (cf. Bobaljik 1995, 2002; Groat \& O’Neil 1996; see below for details). At this point one might ask how subject-initial main declaratives such as (34) can be derived.

(34) $[\mathrm{Se}$ swicola Herodes] cwæd to ðam tungel-witegum.
the treacherous Herod spoke to the star-wise men

'The treacherous Herod spoke to the astrologers.'

(AHTh, I, 82.15; van Kemenade 1987:17)

Here, I assume that the subject does not occupy SpecTP, but rather is to be analyzed as a topic that has moved to SpecCP. Note that this assumption is in line with the cross-linguistic observation (cf. Givón 1976) that subjects are much more frequently topicalized than other elements.

Further arguments in favor of the assumption that OE lacked the EPP come from clauses which lack a nominative DP. In these examples, SpecTP apparently remains empty: in contrast to Modern English, there is no obligatory insertion of expletives with weather verbs, as in (35), extraposed sentential arguments, (36), dative experiencers, (37), and impersonal passives, (38).

norpan $\quad$ sniwde

'it snowed from the north'

(Seafarer, 31; Kiparsky 1997:471)

ðonon cymð oft ðætte...

whence happens often that

'whence happens often that [...]'

(CP, 437.27; Kiparsky 1997:472)

him ofhreow pæs mannes

him-DAT pitied the man-GEN

'he pitied the man'

(AColl, 192.16; Allen 1995:68)

$\begin{array}{llllll}\text { pæet eallum folce } & \text { sy gedemed beforan de } \\ \text { that all } & \text { people-DAT } & \text { be judged } & \text { before } & \text { thee }\end{array}$

'that all the people be judged before you'

(Paris Ps. 9.18; van Kemenade 1997:335)

In previous work, such examples are often analyzed as resulting from the insertion of an empty expletive pro into the subject position (cf. Hulk \& van Kemenade 1995, van Kemenade 1997, Haeberli 1999). But note that this analysis is only motivated (in fact, forced) by the assumption that the EPP is universal and therefore must hold in OE as well. In recent theoretical work, however, the status of the EPP as a universal principle is often called into question (cf. Martin 1999, Grohmann, Drury \& Castillo 2000, Bošković 2002, among others). Moreover, Bondaruk \& CharzyńskaWójcik (2003) provide a set of arguments from the diachronic development of impersonal passives in English that this construction is genuinely subjectless, that is, it does not involve an expletive pro in OE. Let's therefore assume, basically 
following Haider (1993), that only the presence of OVERT expletives can be taken as a clear indication that a given functional head requires its specifier to be filled in the overt syntax, which in a more technical sense means that it hosts an EPP-feature. ${ }^{20}$ Therefore, the absence of an expletive in the above examples can be taken to indicate that $\mathrm{T}$ does not host an EPP-feature in OE.

Finally, we have to account for the distribution of pronouns. In the following section, it is argued that in $\mathrm{OE}$, the featural content of $\mathrm{T}$ can nevertheless overtly attract pronominal elements to SpecTP since they are nothing but a bundle of formal features. In other words, V3 orders with pronominal subjects result from the following structure:

$$
\left[\mathrm{CP} \text { topic }\left[\mathrm{C}^{\prime} \mathrm{C}\left[\mathrm{TP} \text { pron. subject }\left[\mathrm{T}^{\prime} \mathrm{T}+\mathrm{V}_{\text {fin }}\left[{ }_{\nu \mathrm{P}} \ldots\right]\right]\right]\right]\right]
$$

\subsection{The structural position of pronominal subjects in $O E$}

In the previous section, it was argued that the T-head of OE differs from the T-head of Modern English in that it does not host an EPP-feature. In this section, this idea is used to account for the peculiar distributional properties of pronominal subjects in OE which by assumption move systematically to SpecTP, contrasting with full subject DPs. More precisely, the following analysis assumes that a functional head that does not host an EPP-feature can still trigger overt movement to its specifier if the attracted element consists of nothing but formal features. This analysis of pronoun placement goes back to proposals by Roberts (1998) which were originally devised to account for the well-known distributional asymmetries between auxiliaries and main verbs in Modern English.

Roberts (1998) develops an analysis of have/be raising in English which is based on the assumption (cf. Bobaljik 1995, Groat \& O'Neil 1996) that all [-interpretable] features must be eliminated before Spell-Out; only strong attractors require overt pied-piping of the whole category containing the attracted feature $\alpha$. If the attracting feature of a functional head is weak (e.g. the V-feature of T in Modern English), only the formal features $\mathrm{FF}(\mathrm{x})$ of the attractee move up, whereas the rest of the category (including phonological and semantic features) remains in situ (e.g. main verbs in Modern English). If, however, the attracted element consists of nothing but formal features, Move F(eature) (cf. Chomsky 1995) carries the whole category up to the relevant functional node, e.g. auxiliaries in Modern English: attraction of FF(aux) by the weak $\mathrm{V}$-feature of $\mathrm{T}$ gives rise to overt movement of the whole auxiliary which, by assumption, is only a bundle of formal features. In more technical terms: in the course of the operation Move F, formal features are 'stripped away' rather than copied. Therefore, no features are left in the base position of an auxiliary. This in turn will cause Spell-Out to assign a phonological matrix to FF(aux) in its moved position.

Now, my basic proposal is that main aspects of this analysis can be adopted to account for the distribution of pronominal subjects in OE (and perhaps for the analysis 
of clitics/pronouns in general). However, in contrast to the original suggestions by Roberts, the analysis proposed here does not make use of the notion of feature strength, basically for conceptual reasons (cf. Chomsky 2000 for discussion). First, let's make the following assumption with respect to the featural make up of the nominative pronouns of $\mathrm{OE}$ :

(40) The nominative pronouns of $\mathrm{OE}$ are to be analyzed as pure formal feature bundles: [D, nom, $\varphi]$.

On the basis of the premises developed so far, the set of [-interpretable] features of $\mathrm{T}^{0}$, that is, [nom] and $\varphi$-features, can trigger overt raising of a subject pronoun in $\mathrm{OE}$ even if $\mathrm{T}$ does not host an EPP-feature. At the point when $\mathrm{T}$ is introduced into the derivation (i.e. merged with $\nu \mathrm{P}$ ), it seeks a matching element to eliminate its [-interpretable] features. If the closest matching element happens to be a pronominal subject (located in Spec $v$ P), then all its formal features FF(pron.) are pied-piped in the course of Move F (cf. Chomsky 1995). Following Roberts (1998), this has the effect that the pronoun must be phonologically realized at the head position of its movement chain (SpecTP), since according to (40), it consists of nothing more than a bundle of formal features. In contrast, full phrasal subjects have a much richer feature structure, including semantic (e.g. [+animate]) and phonological features (e.g. [kæt]). In a 'single output model' of syntax these features only accompany movement of the formal features to T if pied-piping is forced by an EPP-feature (Bobaljik 1995, 2002; Groat \& O'Neil 1996). However, in the absence of an EPP-feature, T attracts only the set of formal features, whereas semantic and phonological features remain in the base position of the subject, SpecvP, where the phonological features are spelled out. ${ }^{21} \mathrm{On}$ these assumptions, it is possible to account for the fact that subject pronouns must intervene between a finite verb (in $\mathrm{T}^{0}$ ) and a clause-initial topic (in SpecCP) in $\mathrm{OE}:^{.22}$

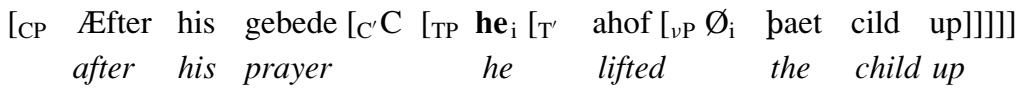

'After this prayer he lifted the child up.'

(AHTh, II.28; van Kemenade 1987:110)

Furthermore, this analysis correctly predicts that the full subject DP appears to the right of the finite verb in examples with 'pseudo V2' such as (42): due to the absence of an EPP-feature in T, only pronouns may undergo 'overt' movement to SpecTP, whereas the phonological features of non-pronominal subjects are spelled out in SpecvP. ${ }^{23}$

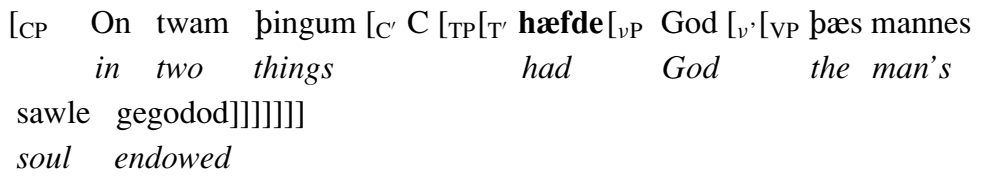

'God had endowed man's soul with two things.'

(AHth, I, 20; van Kemenade 1987:18) 
The analysis of the asymmetries between pronominal and non-pronominal subjects in $\mathrm{OE}$ developed in this section has a number of conceptual advantages if compared to previous models that make use of mechanisms such as cliticization to account for the apparently special behavior of pronouns (e.g. van Kemenade 1987, Pintzuk 1999). First, the dubious character of OE pronouns with respect to phrase structure status and structural position is eliminated. Pronouns start in a position reserved for 'maximal' elements and end in such a position. Second, no countercyclic operations such as head-adjunction are involved. Rather, the distribution of pronominal and non-pronominal subjects follows from general properties of syntactic movement in a single output model that involves the operation Move F. Finally, it is not necessary to assume multiple adjunction possibilities for pronouns (e.g. to the right or left of SpecIP, Pintzuk 1999) to account for the empirical facts of OE.

\section{THE 'LOSS' OF V2 IN ENGLISH'24}

This section focuses on the question how the analysis proposed above can account for the well-known observation that English lost its previously more elaborate V2 character during the Middle English (ME) period, resulting in the form of limited V2 displayed in Modern English. Before we turn to the relevant diachronic processes, let's first clarify which syntactic patterns were lost in the change in question. In section 3, we reached the conclusion that with respect to V2, the main change between $\mathrm{OE}$ and Modern English consists in the loss of V2 orders which exhibit inversion of a non-pronominal subject and the finite verb in the presence of a fronted non-operator. In contrast, the V2 properties of English apparently have not changed much in the context of pronominal subjects. In other words, the grammatical option that was lost were the structures that we called 'pseudo V2', where the finite verb moves to T and the non-pronominal subject stays behind in its theta-position, SpecvP. The fact that the change in question affected only orders with non-pronominal subjects can be taken to indicate that there is a connection between the erosion of V2 system and another change that affected the position of subjects in general, namely the development of an EPP feature that is a characteristic trait of Modern English and forces the overt realization of SpecTP, either by movement of the subject or by insertion of an overt expletive.

A first indication that there is indeed a connection between the two changes in question can be seen in the fact that there are chronological parallels between the loss of $\mathrm{V} 2$ patterns of the type $\left[\mathrm{XP}-\mathrm{V}-\mathrm{DP}_{\text {subj. }}\right.$ ] and a set of diachronic developments that led to an obligatorily filled subject position (in our terms SpecTP). In the theoretical model proposed above, the latter changes can be attributed to the development of an EPP-feature. ${ }^{25}$ According to van Kemenade (1987), the loss of V2 took place at around 1400. In later work (van Kemenade 1997), she somewhat modifies this 
statement, putting the relevant change in the period roughly from 1350 to 1425 . Haeberli (1999) confirms this estimation by taking into account quantitative data from the Penn-Helsinki Parsed Corpus of Middle English. ${ }^{26}$ Interestingly, it can be shown that the loss of V2 patterns is paralleled by changes affecting subjects and in particular the subject position. Van Kemenade (1997) demonstrates that English lost subjectless structures (cf. (35)-(38) above) at about the same time, that is 'in the last part of the fourteenth and the early fifteenth century' (p. 349), referring to work by van der Wurff (1990) on the loss of subjectless easy to please constructions (cf. also Fischer et al. 2000), Butler (1980) on the rise of there in existentials, and Allen (1995) on the loss of subjectless impersonal constructions with experiencer verbs and passives. In a similar vein, Haeberli (1999:403ff.) argues for systematic parallels between the erosion of the V2 system and the decline of subjectless constructions, citing quantitative data from Breivik $(1989,1990)$, where it is shown that there is a rapid increase of the use of there in existential sentences in the time between 1225 and 1425 (from around 30\% to over 80\%). Both van Kemenade (1997) and Haeberli (1999) (cf. also Hulk \& van Kemenade 1995; Haeberli 2002) then go on to argue that the close connection between the loss of V2 and the loss of subjectless structures motivates an analysis that reduces the apparently independent changes to a single diachronic development, namely the loss of expletive pro-drop due to the erosion of verbal inflection. More specifically, Haeberli $(1999,2002)$ attributes the decline of superficial V2 orders to the loss of an empty expletive pro that is inserted as specifier of AgrsP in order to satisfy the EPP, thereby blocking overt movement of non-pronominal subjects to this position in $\mathrm{OE}$. He derives the latter change from an independent morphological change that significantly impoverished the verbal agreement morphology in the ME period. ${ }^{27}$ As a result, expletive pro could no longer be licensed by the verbal agreement morphology and dropped out of the grammar. Accordingly, the only remaining possibility to satisfy the EPP was overt movement of the subject to SpecAgrsP across the finite verb that is by assumption located in Agrs. Similar to the account to be proposed below, this disrupts the PFadjacency between the finite verb and a topic in SpecCP, and therefore leads to the loss of V2 orders. Note, however, that Haeberli's analysis fails to account for the fact that there is a chronological parallel between the loss of V2 and the development of overt expletives, since it is not clear why the loss of covert expletives should provoke the development of overt counterparts, especially when movement of the subject provides an alternative way to satisfy the EPP. Moreover, this account raises the question why structures similar to those found in OE are not possible with an overt expletive in ME prior to the loss of verb movement to Agrs. To the best of my knowledge, examples of the kind schematically given in (43) are not attested in any historical stage of English. ${ }^{28}$

$$
\text { *[CP The book [AgrsP there [Agrs' } \operatorname{read}[\mathrm{TP}[\mathrm{VP} \text { the student]]]]] }
$$


In what follows, I propose an analysis couched within the theoretical model proposed in section 4 . This approach shares basic insights with the accounts suggested by van Kemenade (1997) and Haeberli $(1999,2002)$, but crucially differs from them in not assuming a universal EPP (which forces the assumption of empty expletives in their analyses, see above). Rather, it is claimed that the diachronic development of an EPP-feature required SpecTP to be overtly filled, thereby disrupting the linear adjacency of clause-initial topics and the finite verb in T. This led to the loss of 'pseudo V2' configurations, giving rise to the familiar V3 topic-constructions of present day English. The development in question is illustrated by the following pair of phrase markers: ${ }^{29}$

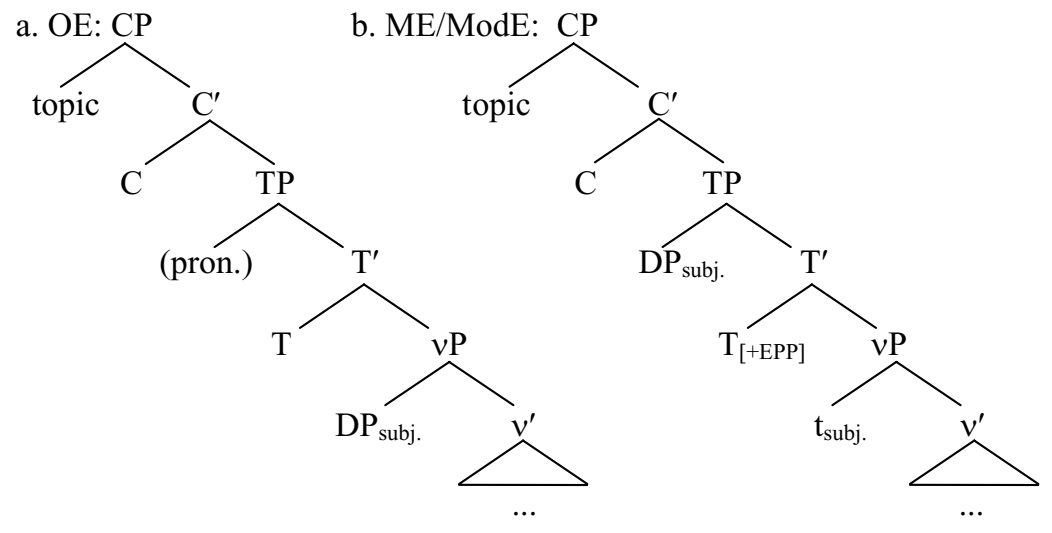

In other words, the partial loss of V2 involved no changes concerning the structural positions of topics (SpecCP) and the finite verb $\left(\mathrm{T}^{0}\right)$. Rather, superficial V2 patterns disappeared because SpecTP came to be obligatorily filled by the subject (paralleled by the development of overt expletives). On these assumptions, the 'loss of V2' in the Middle English period comes out as an epiphenomenon, resulting from the independently motivated development of an EPP-feature. ${ }^{30}$

However, if the loss of V2 is reduced to the development of an EPP-feature in $\mathrm{T}$, one has to address the question of how the latter change came about. Note that this question actually boils down to another still unresolved question, namely the exact nature of the EPP (e.g. whether it can be derived from independent factors; cf. the papers in Svenonius 2001). Here, one might follow the traditional idea (cf. Sapir 1921; Kiparsky 1997 for a more recent rendition) that the loss of inflectional morphology required arguments to occur in fixed structural positions ('positional licensing' in the sense of Kiparsky 1997). ${ }^{31}$ More specifically, the loss of case and verbal agreement morphology led to a situation where subjects could only be licensed in a Spec-head relationship with their case-assigning head, T. This approach seems to account quite neatly for the diachronic facts of English. However, it runs into some problems if we take a look at a language such as Icelandic, which exhibits very 
rich verbal and nominal inflection, but crucially lacks free reordering of nominal arguments (in contrast to e.g. Modern German or OE). In other words, Icelandic apparently has to rely on positional licensing of arguments despite the fact that its case system is rich enough to unambiguously identify the grammatical relations taken up by nominal arguments (cf. Thráinsson 1997). Hence, the putative strong correlation between inflectional morphology and the position of nominal arguments does not hold and it is not clear why the loss of the former should force the learner to acquire fixed structural positions for nominal arguments.

In the remainder of this section, I want to explore another approach which derives from the idea that the development of the EPP is connected to licensing requirements of Tense (cf. Roberts \& Roussou 2001) and the independent development of a rigid tense system in the history of English.

As noted earlier, in n. 23, there is one frequently attested word order option in OE that seems to be at odds with the analysis developed in section 4. In section 3.1.2 above, it has been noted that there are V3 orders where the finite verb is preceded by a scene-setting temporal adverb and a full nominal subject, repeated here for convenience:

a. [Æfter peossum wordum] [se Hælend] cwæp to his leornerum... after these words the Savior spoke to his disciples

(Blickling 135; Swan 1994:241)

b. [Her] [Oswald se eadiga arceb] forlet pis lif. in-this-year Oswald the blessed archbishop forsook this life (ASC, Laud (992); Kroch \& Taylor 1997:304)

If, as proposed in section 4, only pronominal subjects can move overtly to (or rather, be spelled out in) SpecTP, the question arises how full nominal subjects can show up in exactly this position, giving rise to V3 orders such as (45). A possible (albeit not very enlightening) solution is to adopt Rizzi's (1997) split CP structure for the analysis of OE (cf. Roberts 1996) and analyze examples such as (45) as cases of multiple topicalization, targeting different specifier positions in the $\mathrm{C}$ domain. ${ }^{32}$ However, a more interesting answer to this problem becomes available if we consider the sentences in (45) as early instances of the Modern English pattern, i.e. with the nominal subject occupying SpecTP and relate these patterns to the loss of the superficial V2 orders generated by the 'pseudo V2' configuration discussed above.

Then, the question arises of what forces movement of the subject to SpecTP in these examples. Here, the basic proposal I want to put forward is that movement of the subject is triggered by further licensing requirements of Tense, apart from those already fulfilled by verb movement. More precisely, it is assumed that in examples such as (45), the scene-setting adverb in SpecCP anchors the utterance to a reference time specified in the preceding discourse context. This in turn induces the presence of a tense variable in T that must be bound by a DP in SpecTP (which, according 
to Roberts \& Roussou 2001, is the essence of the EPP; cf. Davis 1998 for similar ideas). In other words, the claim is that in OE, the presence of this tense variable is confined to contexts with fronted scene-setting adverbs (recall that movement into the C domain connects topics to the discourse context, cf. Rizzi 1997) that force a certain temporal setting of the utterance (a contextually induced EPP, so to say). The development of a general EPP (i.e. a tense variable in T) that requires overt realization of SpecTP in all (finite) contexts can then perhaps be related to another change, namely the development of an elaborate and rigid system of tenses, with a clear functional differentiation of, e.g. past and perfect tense, which is a characteristic of Modern English (in OE, there are only two tenses, past and non-past; cf. Denison 1993 for a comprehensive overview of the diachronic developments in question). Interestingly, there are some hints that the latter development took place at about the same time as the changes discussed above (i.e. the loss of V2 and subjectless constructions). For example, Bauer (1970) claims (in his study of the use of different tenses in the works of Chaucer and Gower) that the differentiation of past and perfect tense was completed by and large by the end of the 14th century. Another indication that these suggestions are perhaps on the right track comes from the fact that in a language such as German, the absence of EPP effects (cf. Haider 1993, Roberts \& Roussou 2001) goes hand in hand with a - compared to English - much less rigid tense system, where past and perfect tense are freely interchangeable and the present tense can assume all kinds of temporal functions (cf. Zeller 1994, Grewendorf 1995). It must be admitted, however, that the hypothesis in question is still fairly speculative at this stage. To be sure, more research will be necessary to strengthen the proposed link between the EPP and properties of the tense system, which should be based on a more detailed study of the diachronic changes affecting the English tense system as well as a larger sample of languages.

\section{SUMMARY}

This paper presented further arguments for the claim (cf. Kiparsky 1995; Eythórsson 1995 1996) that V-to-C movement in clauses with a fronted operator such as whquestions constitutes the historical core of the Germanic V2 phenomenon. Therefore, the historical system shares basic properties with the limited V2 properties of Modern English, revealing the existence of a diachronic continuity ranging from Gothic over OE to present day English.

In the first part of the paper, I considered data from the earliest Germanic records available, showing that already in Gothic, systematic V-to-C movement occurs in the same contexts that trigger this operation in Modern English. Special attention was paid to apparent counter-examples that arise in the context of elements such as pronouns and particles that appear in second position, with the finite verb in a position further to the right. Here, it was shown that all problematic cases can be attributed to the fact that the Gothic bible is a very literal translation from Greek. More specifically, 
all alleged counter-examples were shown to exactly imitate the word order patterns found in the corresponding clauses of the Greek original. Therefore, it was concluded that these examples do not constitute a problem for the claim that wh-questions in Gothic should be considered early instances of V2.

In the second part of the paper, it was argued that the core of the V2 syntax of OE is very similar to the form of limited V2 found in Modern English as well. Following insights by Pintzuk (1999), Haeberli (1999) and many others, it was claimed that the - compared to Modern English - apparently more elaborate V2 properties of OE reduce to the frequently attested order $\left[\right.$ Topic $-\mathrm{V}-\mathrm{DP}_{\text {subj. }}$. This pattern was attributed to a configuration labeled 'pseudo-V2', where clause-initial phrase and finite verb are not in a Spec-head configuration; the V2 patterns in question were then shown to result from a merely linear adjacency between SpecCP and $\mathrm{T}^{0}$. In turn, V3 patterns involving pronominal subjects were analyzed in terms of movement of these pronouns to SpecTP. Here it was claimed, following ideas by Roberts (1998), that the set of [-interpretable] case and $\varphi$-features located in T can trigger overt movement if the attracted element consists of nothing but a bundle of formal features. In contrast, full nominal subjects must reside in their theta-position in OE, due to the absence of an EPP feature in T. The last section of the paper focused on the partial loss of V2 properties in the Middle English period. Here it was claimed that this change actually reduces to another change in the history of English, namely the independent development of an EPP-feature in $\mathrm{T}$ that forces the lexical realization of SpecTP, thereby disrupting the 'pseudo V2' configuration typical of OE. Finally, some tentative remarks were added concerning the trigger of the latter development, suggesting that the rise of the EPP is related to changes affecting the tense system of English.

\section{ACKNOWLEDGEMENTS}

I would like to thank the participants of the Workshop on V2 in Verona, ConSole 8 in Vienna and audiences at the Universities of Frankfurt, Jena and Stuttgart for useful comments on earlier versions of this paper. In addition, I would especially like to thank Josef Bayer, Cecilia Falk, Günther Grewendorf, Shin-Sook Kim, Melanie Klepp, Cécile Meier, Tomas Riad, Ian Roberts, Joachim Sabel, Peter Sells, Carola Trips, Sten Vikner and two anonymous NJL reviewers for valuable suggestions and criticism, which helped to improve things considerably. All remaining errors are, of course, mine.

\section{NOTES}

1. Furthermore, there are 23 cases where an overt pronoun translates as a null subject in an embedded clause. In all these examples, the pronoun directly follows the complementizer. 
Again, this is similar to the placement of pronouns in the modern Germanic V2 languages, cf.

(i) witum ei bu kant alla

know that you know all

Gk. oidamen hoti oidas panta

'We know that you know all the things.'

(Jo. 16,30; Ferraresi 1997:59)

2. There is only a single example where pan (without $-u h$ ) immediately follows a $w h$-phrase. Notice, however, that (apart from the fact that pan renders the Greek second position element $d e$ ) this is actually not a relevant example, since the particle splits up a complex wh-phrase (i.e. it is inserted after the initial word), which is in turn directly followed by the finite verb.

(i) has ban izwara skalk aigands arjandan aippau haldandan, who PRT of-you.PL servant having ploughing or feeding (cattle) saei atgaggandin af haibjai qibai: suns hindarleip anuhkumbei? who coming back from field would-say at once come over sit down to eat 'But which of you, having a servant plowing or feeding cattle, who came in from the field, will say to him: go and sit down to eat at once.'

(Lk. 17,7; TITUS)

3. According to Eythórsson (1995), this is the only function of $-u h$. However, Ferraresi (1997) shows that the distributional properties of $-u h$ are actually more complex. She argues (basically following Klein 1994) that apart from its coordinating function, $-u h$ also functions as a discourse particle that serves to mark anaphoric relations across clauses. Furthermore, she shows that $-u h$ is not in complementary distribution with the tonic conjunction jah. In the following examples, $-u h$ appears in the first of two clauses conjoined by jah. From these facts, Ferraresi concludes that $-u h$ does not always function as a coordinating particle.

(i) a. uz-uh-iddja fram attin jah atiddja in bana fairuu forth-PRT-came from father and came into the world

'I came forth from the Father and came into the world.'

(Jo. 16,28; Ferraresi 1997:108)

b. ip is wiss-uh mitonins ize jah qap du pamma mann... but he knew-PRT thoughts their and said to the man

'But he knew their thoughts and said to the man...' (Lk. 6,8; Ferraresi 1997:108)

Note that in (ib), $-u h$ is placed after the subject pronoun and the finite verb (i.e. it occurs in third position). Eythórsson (1995) shows that this ordering is always observed when a definite subject is topicalized ( 15 examples).

4. Historically, jah derives from ja + -uh, cf. Eythórsson (1995:54, fn. 12).

5. This perhaps suggests an analysis where the ultimate position of these particles is determined by post-syntactic processes that may shift a clitic element minimally to the left or right in order to satisfy PF-conditions. One such operation is PROSODIC INVERSION, as argued for by Halpern (1992). Prosodic Inversion affects prosodic categories to satisfy $\mathrm{PF}-$ conditions such as second position effects. A characteristic of this process is that it does not respect phrase boundaries. Schütze (1994) discusses the well-known case of second position clitics in Serbo-Croation the placement of which may lead to a split of other phrases, similar to the Gothic examples discussed above. However, see Ćavar \& Wilder 
(1999) and Ćavar \& Fanselow (2002) for a critique of phonological accounts of the SerboCroation facts, and an alternative analysis in terms of syntactic movement. In a similar vein, Eythórsson $(1995,1996)$ suggests an analysis of the splits found in Gothic in terms of syntactic head movement (incorporation in the sense of Baker 1988).

6. $u h \rightarrow u p$ due to assimilation rules.

7. According to Bauer (1979:171) de is 'one of the most commonly used Gk. particles, used to connect one clause with another when it is felt that there is some contrast between them, though the contrast is often scarcely discernible. Most common translations: but, when a contrast is clearly implied; and, when a simple connective is desired'.

8. In addition, as noted above, there are 122 cases where ban co-occurs with - $u h$.

9. No relevant examples were found with the wh-words his (MASC/NEUT.GEN), hamma (MASC/NEUT.DAT), hizai (FEM.DAT), hana (MASC.ACC), harjis 'which one', bihêe 'where of', hileiks 'what ... like', helauda 'how big'.

10. In addition, I have found two instances (1Cor. 15,29 and 1Cor. 15,30) where the second position in a $w h$-question is occupied by the Gothic particle bau which, according to Wright (1924), is best translated as 'then, in that case' in this environment. Again, it can be shown that in both instances, the Gothic particle renders a Greek second position element, kai, cf.

$\begin{array}{lllll}\text { (i) duhe bau daupjand } & \text { faur ins? } \\ \text { why } & P R T & \text { baptize-3PL } & \text { for } & \text { them }\end{array}$

Gr. ti kai baptizontai huper autōn

'Why then do they baptize for them?

(1Cor. 15,29; TITUS)

(ii) duhe bau weis bireikjai sijum heilo hoh? why $P R T$ we in-danger are hour every

Gr. ti kai hēmeis kinduneuomen pasan hōran

'Why are we in danger every hour?'

(1Cor. 15,30; TITUS)

11. The relevant bible passages are as follows: Gk. de rendered by Gothic ban: Lk. 7,17; de rendered by -uh pan: Mt. 25,38; Mt. 25,39; 1Cor. 4,7; de rendered by nu: Mt. 11,16; Jo. 9,21; gar rendered by auk: Mk. 8,36; Rom. 11,34; 1Cor. 4,7; 1Cor. 10,29; 2Cor. 12,13; Phil. 1,18; 1Thess. 2,19; 1Thess. 3,9; oun rendered by nu: Jo. 9,19; Lk. 7,31; Lk. 7,42; Lk. 20,15; Mk. 15,12; Rom. 7,7; Rom, 9,14; Rom. 9,30; Rom. 10,14; 1Cor. 10,19; 1Cor. 4,26; Phil. 2,1; nun rendered by $n и$ : Jo. 6,42.

12. Note that there are very few examples in which the pronoun follows the finite verb and a clause-initial topic, resulting in V2-patterns similar to the modern Germanic languages, cf.

(i) eadig eart bu abgar

blessed art thou Abgar

'blessed art thou, Abgar'

(ÆLS 24.113; Pintzuk 1999:122)

Quantitative data raised by Haeberli (2000:13) confirms the claim that V3 is systematically found with non-operators preceding pronouns in OE. In seven out of ten OE text samples, inversion with a pronominal subject does not occur at all. In the remaining three texts, there are only six examples (Bede: 1; Chronicle A: 1; Orosius: 4) where the subject pronoun undergoes inversion (leading to V2), contrasting with 89 examples where no inversion takes place. 
13. Following van Kemenade (1987), the fact that elements such as $b a$ force V2 (i.e. V-to-C movement) is commonly accounted for by the assumption that these elements should be analyzed as operators on a par with wh-phrases and negation. However, it is not quite obvious why adverbs like $b a$ and bonne should have the status of syntactic operators. The only motivation for this analysis seems to come from the fact that they apparently trigger verb movement. Moreover, note that the Modern English equivalent then does not trigger verb movement anymore, despite the fact that Modern English preserved V-to-C movement in operator contexts (see above):

(i) *Then read John/he the book.

An alternative analysis of temporal adverbs such as $b a$ becomes available if we capitalize on the observation that these adverbs are in complementary distribution with pronouns in preverbal position (in main clauses). This can be taken to suggest that both types of elements compete for the same structural position, which is identified below as SpecTP. Then, V2 order with $b a$ is not the result of verb movement to $\mathrm{C}$, but rather follows from the assumption that the pronoun must reside in its theta-position when $b a$ is merged in SpecTP. This analysis is further elaborated on in Fuss \& Trips (in preparation).

14. Note that $\mathrm{OE}$ and Modern English further differ due to the fact that in general, movement of finite verbs is confined to auxiliaries in Modern English. However, it can be shown that this difference is not part of the change affecting the V2 properties of English, but rather the outcome of an independent development that took place much later, in Late Middle English/Early Modern English (cf. Kroch 1989, Roberts 1993, Lightfoot 1999).

15. See Haeberli (2000) for arguments that these violations of V2 cannot be analyzed as instances of verb-final order, which was an - albeit very limited - word order option in main clauses of OE (cf. Pintzuk 1999).

16. The analysis suggested by Roberts (1996) differs somewhat from the other proposals since it makes use of the Split-C hypothesis of Rizzi (1997). According to Roberts, V3 orders such as (23) follow from a configuration where the finite verb moves to the lowest head of the C-system $\left(\mathrm{Fin}^{0}\right)$, with the subject pronoun in SpecFinP and the fronted XP in the Spec of some higher functional projection (TopP or ForceP).

17. Most generative work on OE endorses in some form or other the Rich Agreement Hypothesis (Holmberg \& Platzack 1988, Platzack \& Holmberg 1989, Roberts 1993, Bobaljik 1995, Rohrbacher 1999), according to which verb movement is triggered by rich inflectional morphology; however see Alexiadou \& Fanselow (2001) for a discussion of general problems associated with this hypothesis. Moreover, see Fuss \& Trips (2002) for arguments that the finite verb does not leave the $(\nu \mathrm{P} / \mathrm{VP}$ domain in embedded clauses of OE, an observation which is in conflict with the Rich Agreement Hypothesis.

18. In main clauses, Tense and the verb are related by means of a syntactic chain that is established by V-to-T movement. In non-embedded clauses, this operation 'anchors the temporal reference of the event on the time of the utterance' (Bennis \& Hoekstra 1989:26). In contrast, Tense of embedded clauses is dependent on the temporal anchoring of the matrix clause (see Enç 1987). By assumption, this relation is mediated in a local fashion by the complementizer (which is selected by the matrix verb), rendering V-to-T superfluous and therefore by economy impossible. Accordingly, Fuss \& Trips (2002) analyze word order variation found in embedded clauses of $\mathrm{OE}$ in terms of competing phrase structural options within the extended verbal projection (i.e. ( $\nu \mathrm{P} / \mathrm{VP})$. 
19. Cecilia Falk pointed out to me that according to this analysis, other nominatives that do not receive their theta role in SpecvP, such as subjects of passives (or arguments of unaccusatives), should also be licensed in their theta position (either in SpecVP or as a sister of the main verb), as for example in (32), where the nominative DP follows the passive participle. Furthermore, the nominative DP can show up in a position to the left of the passive participle, giving rise to the order [topic $-\mathrm{aux}_{\mathrm{fin}}-\mathrm{DP}_{\text {nom }}-$ passive participle], cf.

(i) on bæm wæron eac ba men ofslægene
on it

'On it too the men were slain.'

(Mitchell \& Robinson 1992:111)

Note that examples such as (i) presumably do not involve leftward movement of the nominative DP over the passive participle to, say, SpecvP. Rather, they display the nominative DP in its base position to the left of the main verb, given the fact that $\mathrm{OE}$ predominantly exhibits OV phrase structure within VP (with VO phrase structure as a minority pattern; see Pintzuk 1999, Fuss \& Trips 2002 for discussion).

20. The exact nature of this feature is still an unresolved question; with respect to the 'classic' EPP feature located in Infl (or, T/Agrs) the prevalent proposals are [D] (Chomsky 1995) or [person] (Chomsky 2000); see the papers in Svenonius (2001) for discussion.

21. Presumably this is still the case in Modern German: Haider (1993) advances several arguments for the claim that subjects can remain in a VP-internal position in Modern German (cf. Roberts \& Roussou 2001 for a recent version of this view).

22. At first sight, V3 orders involving object pronouns seems to raise a problem for this analysis, since it is unclear how object pronouns can be attracted by the [-interpretable] features of $\mathrm{T}$ in cases where the latter match the formal features of a postverbal nominative subject as in the following example:
(i) Fela spella him sædon ba Beormas
many stories him told the Permians

'the Permians told him many stories' (Oros., 14.27; van Kemenade 1987:114)

First, note that movement of the pronoun over the base position of the subject raises no problem with respect to locality conditions such as the Minimal Link Condition or Relativized Minimality: After raising to the outer SpecvP to check object case, object pronoun and subject DP are equidistant to SpecTP (cf. Chomsky 1995, Collins 1997). Further movement of the object pronoun to SpecTP can then perhaps be triggered by the set of $\varphi$-features located in T, in a way parallel to the phenomenon of quirky subjects in Modern Icelandic (but crucially without involving the EPP).

23. As one anonymous reviewer pointed out, this analysis raises the question how $\mathrm{V} 3$ orders of the type [XP $-\mathrm{DP}_{\text {subj. }}-\mathrm{V}$ ] can be derived (see section 3.1.2 above). This question is addressed in section 5 .

24. Note that the term 'loss of V2' is actually somewhat misleading if it is used to refer to the diachronic development discussed in this section, as one anonymous reviewer pointed out to me. First, it is clear that English has not lost its V2 properties altogether, as is clear from the data discussed in section 1. Second, it is often stressed (cf. Eythórsson 1995, 1996; Haeberli 1999) that OE was not a 'real' V2 language (in the sense of the modern Germanic V2 languages) to begin with. Therefore, it is kind of odd to speak of the 'loss of V2'. I will 
nevertheless continue to use the term 'loss of V2' to refer to the loss of the 'pseudo V2' patterns found in $\mathrm{OE}$.

25. In earlier work, the latter developments are often attributed to the loss of empty expletives in the history of English (cf. Hulk \& van Kemenade 1995, van Kemenade 1997, Haeberli 1999).

26. Warner (1997) speculates that the change in question might have begun even over a century earlier as a long-term gradual change that involved competition of different grammars, giving rise to the multitude of word order patterns displayed by Old and Early Middle English.

27. Due to the loss of the infinitival ending $-n$, the singular verbal agreement endings were no longer distinct from the infinitive.

28. But see Haeberli (1999:406) for some discussion of this problem.

29. Note that phrase marker (44b) does not capture the fact that main verbs occupy different structural positions in ME and Modern English. In ME, all finite verbs (auxiliaries AND main verbs) move to T. In contrast, in Modern English this position is only accessible for finite auxiliaries/modals, whereas finite (at least transitive and unergative) main verbs only undergo short movement to $v$ (cf. Larson 1988, Chomsky 1995, Collins 1997).

30. Sten Vikner pointed out to me that Mainland Scandinavian seems to represent a problem for this proposal: the presence of Infl-related expletives indicates the existence of an EPPfeature in these languages. Nevertheless, Mainland Scandinavian has not lost regular V2 in main clauses. However, this situation might be the result of a different chronological order of the relevant historical processes, with the development of full V2 preceding the development of an EPP-feature. This hypothesis is confirmed by the historical facts: Falk (1993) shows that Old Swedish (1225-1526) is a full V2 language that has not yet developed obligatory overt (expletive) subjects.

31. As Sapir (1921:166) puts it: 'As the inflected forms of English became scantier, as the syntactic relations were more and more inadequately expressed by the forms of the words themselves, position in the sentence gradually took over functions originally foreign to it.'

32. An anonymous reviewer suggested that examples such as (45) might be analyzed in terms of the absence of V-to-T movement. Then, the verb is presumably located in $v$, similar to embedded clauses (cf. Fuss \& Trips 2002). In light of the proposals made below, one might speculate that verb movement does not have to take place in these examples due to the fact that Tense can be licensed by the presence of the subject in SpecTP. I leave this point open for future research.

\section{REFERENCES}

Alexiadou, Artemis \& Gisbert Fanselow. 2001. On the correlation between morphology and syntax: the case of V-to-I. Ms., University of Potsdam.

Allen, Cynthia. 1995. Case Marking and Reanalysis: Grammatical Relations from Old to Early Modern English. Clarendon, Oxford.

Baker, Mark. 1988. Incorporation: A Theory of Grammatical Function Changing. Chicago: Chicago University Press. 
Battye, Adrian \& Ian Roberts (eds.). 1995. Clause Structure and Language Change. Oxford: Oxford University Press.

Bauer, Gero. 1970. Studien zum System und Gebrauch der 'Tempora' in der Sprache Chaucers and Gowers (Wiener Beiträge zur englischen Philologie 73). Vienna: Wilhelm Braunmüller.

Bauer, Walter. 1979. A Greek-English Lexicon of the New Testament and Other Early Christian Literature (2nd ed.). Chicago: University of Chicago Press.

Behaghel, Otto. 1932. Deutsche Syntax IV. Heidelberg: Winter.

Bennis, Hans \& Teun Hoekstra. 1989. Why Kaatje was not heard sing a song. In Dany Jaspers, Wim Klooster, Yvan Putseys \& Pieter Seuren (eds.), Sentential Complementation and the Lexicon. Dordrecht: Foris, 21-40.

Bobaljik, Jonathan. 1995. Morphosyntax: The Syntax of Verbal Inflection. Ph.D. dissertation, MIT.

Bobaljik, Jonathan. 2002. A-chains at the PF-interface: copies and 'covert' movement. Natural Language \& Linguistic Theory 20, 197-267.

Bondaruk, Anne \& Magdalena Charzyńska-Wójcik (2003). Expletive pro in impersonal passives in Irish, Polish and Old English. Linguistische Berichte 195, 325-362.

Boškovic, Željko. 2002. A-movement and the EPP. Syntax 5.3, 167-218.

Braune, Wilhelm \& Ernst Ebbinghaus. 1981. Gotische Grammatik. Tübingen: Niemeyer. Breivik, Leiv. 1989. On the causes of syntactic change in English. In Leiv Breivik \& Ernst Håkon Jahr (eds.), Language Change: Contributions to the Studies of its Causes. Berlin: Mouton de Gruyter, 29-70.

Breivik, Leiv. 1990. Existential 'there' : A Synchronic and Diachronic Study. Oslo: Novus Press.

Brugmann, Karl \& Berthold Delbrück. 1900. Grundriss der vergleichenden Grammatik der Indogermanischen Sprachen (vol. 5). Strassburg: Trübner.

Butler, Milton Chadwick. 1980. Grammatically Motivated Subjects in Early English. Ph.D. dissertation, University of Texas, Austin.

Cardinaletti, Anna \& Ian Roberts. 1991. Clause structure and X-second. Ms., Università di Venezia and Université de Genève. [Published in Guglielmo Cinque (ed.). 2002.

Functional Structure in DP and IP: The Cartography of Syntactic Structures (vol. 1). Oxford: Oxford University Press, 123-166.]

Ćavar, Damir \& Gisbert Fanselow. 2002. Discontinuous constituents. Paper presented at the University of Frankfurt.

Ćavar, Damir \& Chris Wilder. 1999. 'Clitic third' in Croation. In Henk van Riemsdijk (ed.), Clitics in the Languages of Europe. Berlin: Mouton de Gruyter, 429-467.

Chomsky, Noam. 1995. The Minimalist Program. Cambridge, MA: MIT Press.

Chomsky, Noam. 2000. Minimalist inquiries: the framework. In Roger Martin, David

Michaels \& Juan Uriagereka (eds.), Step by Step. Cambridge, MA: MIT Press, 89-155.

Collins, Chris. 1997. Local Economy. Cambridge, MA: MIT Press.

Davis, Henry. 1998. Person splits, $\varphi$-features and temporal architecture. GLOW Newsletter 40, 83-84.

Denison, David. 1993. English Historical Syntax. London: Longman.

Enç, Mürvet. 1987. Anchoring conditions for Tense. Linguistic Inquiry 18, 633-657.

Eythórsson, Thórhallur. 1995. Verbal Syntax in the Early Germanic Languages. Ph.D. dissertation, Cornell University.

Eythórsson, Thórhallur. 1996. Functional categories, cliticization, and verb movement in the Early Germanic languages. Höskuldur Thráinsson, Samuel. D. Epstein \& Steve Peter (eds.), Studies in Comparative Germanic Syntax II. Dordrecht: Kluwer, 109-139. 
Falk, Cecilia. 1993. Non-referential subjects and agreement in the history of Swedish. Lingua 89, 143-180.

Ferraresi, Gisella. 1997. Word Order and Phrase Structure in Gothic: A Comparative Study. Ph.D. dissertation, Universität Stuttgart.

Fischer, Olga, Ans van Kemenade, Willem Koopman \& Wim van der Wurff. 2000. The Syntax of Early English. Cambridge: Cambridge University Press.

Fourquet, Jean. 1938. L'Ordre des éléments de la phrase germanique ancien. Etudes de syntaxe de position. Paris: Les Belles Lettres.

Fuss, Eric. 1998. Zur Diachronie von Verbzweit. Die Entwicklung von Verbstellungsvarianten im Deutschen und Englischen. M.A. thesis, Universität Frankfurt/Main.

Fuss, Eric \& Carola Trips. 2002. Variation and change in Old and Middle English. On the validity of the Double Base Hypothesis. Journal of Comparative Germanic Linguistics 4, 171-224.

Fuss, Eric \& Carola Trips. (In preparation). pa, ponne, and V2 in Old and Middle English. Ms., Universities of Frankfurt \& Stuttgart.

Givón, Talmy. 1976. Topic, pronoun and grammatical agreement. In Charles Li (ed.), Subject and Topic. London \& New York: Academic Press, 149-88.

Green, Georgia. 1980. Some wherefores of English inversions. Language 56, 582-601.

Grewendorf, Günther. 1995. Präsens und Perfekt im Deutschen. Zeitschrift für Sprachwissenschaft 14:1, 72-90.

Grewendorf, Günther. 2002. Minimalistische Syntax. Tübingen: Francke.

Groat, Erich \& John O'Neil. 1996. Spell-Out at the LF-interface. In Werner Abraham et al. (eds.), Minimal Ideas. Amsterdam: John Benjamins, 113-139.

Grohmann, Kleanthes, John Drury \& Juan Carlos Castillo. 2000. No more EPP. In Proceedings of WCCFL 19. Somerville, MA: Cascadilla Press, 139-152.

Haider, Hubert. 1993. Deutsche Syntax - Generativ. Tübingen: Gunter Narr.

Halpern, Aaron. 1992. Topics in the Placement and Morphology of Clitics. Ph.D. dissertation, Stanford University.

Haeberli, Eric. 1999. Features, Categories and the Syntax of A-positions: Synchronic and Diachronic Variation in the Germanic Languages. Ph.D. dissertation, University of Geneva.

Haeberli, Eric. 2000. Observations on the loss of verb second in the history of English. Ms., University of Reading.

Haeberli, Eric. 2002. Inflectional morphology and the loss of V2 in English. In David Lightfoot (ed.), Syntactic Effects of Morphological Change. Oxford: Oxford University Press, 88-106.

Holmberg, Anders \& Christer Platzack. 1988. On the role of inflection in Scandinavian syntax. Working Papers in Scandinavian Syntax 42, 25-42.

Hulk, Aafke \& Ans van Kemenade. 1995. Verb second, pro-drop, functional projections and language change. In Battye \& Roberts (eds.), 227-256.

Kemenade, Ans van. 1987. Syntactic Case and Morphological Case in the History of English. Ph.D. dissertation, Rijksuniversiteit te Utrecht.

Kemenade, Ans van. 1997. V2 and embedded topicalization in Old and Middle English. In van Kemenade \& Vincent (eds.), 326-351.

Kemenade, Ans van. 1999. Sentential negation and clause structure in Old English. In Ingrid Tieken-Boon van Ostade, Gunnel Tottie \& Wim van der Wurff (eds.), Negation in the History of English. Berlin \& New York: Mouton de Gruyter, 147-165.

Kemenade, Ans van \& Nigel Vincent (eds.). 1997. Parameters of Morphosyntactic Change. Cambridge: Cambridge University Press. 
Kiparsky, Paul. 1995. Indoeuropean origins of Germanic syntax. In Battye \& Roberts (eds.), $140-169$.

Kiparsky, Paul. 1997. The rise of positional licensing. In van Kemenade \& Vincent (eds.), 460-493.

Klein, Jared. 1994. Gothic paruh, panuh and -(u) pan. Indogermanische Forschungen 99, 253-276.

Koopman, Willem. 1998. Inversion after single and multiple topics in Old English. In Jacek Fisiak \& Marcin Krygier (eds.), Advances in English Historical Linguistics. Berlin: Mouton de Gruyter, 135-149.

Kratzer, Angelika. 1996. Severing the external argument from its verb. In Johan Rooryck \& Laurie Zaring (eds.), Phrase Structure and the Lexicon. Dordrecht: Kluwer, 109-137.

Kroch, Anthony. 1989. Reflexes of grammar in patterns of language change. Journal of Language Variation and Change 1.3, 199-244.

Kroch, Anthony \& Ann Taylor. 1997. Verb movement in Old and Middle English: dialect variation and language contact. In van Kemenade \& Vincent (eds.), 297-325.

Larson, Richard. 1988. On the double object construction. Linguistic Inquiry 19, 335-391.

Lightfoot, David. 1995. Why UG needs a learning theory: triggering verb movement. In Battye \& Roberts (eds.), 31-52.

Lightfoot, David. 1999. The Development of Language: Acquisition, Change, and Evolution. Oxford: Blackwell.

Longobardi, Giuseppe. 1994. La posizione del verbo gotico e la sintassi comparata dei complementatori germanici: alcune riflessioni preliminary. In Palmira Cipriano, Paolo Di Giovine \& Marco Mancini (eds.), Miscellanea di studi linguistici in onore di Walter Belardi. Rome: Il Calamo, 353-373.

Martin, Roger. 1999. Case, the Extended Projection Principle, and minimalism. In Samuel Epstein \& Norbert Hornstein (eds.), Working Minimalism. Cambridge, MA: MIT Press, $1-25$.

May, Robert. 1985. Logical Form. Cambridge, MA: MIT Press.

Mitchell, Bruce \& Fred C. Robinson. 1992. A Guide to Old English (5th edn.). Oxford: Blackwell.

Pintzuk, Susan. 1993. Verb seconding in Old English: verb movement to Infl. The Linguistic Review 10, 5-35.

Pintzuk, Susan. 1999. Phrase Structures in Competition: Variation and Change in Old English Word Order. New York: Garland.

Pesetsky, David \& Esther Torrego. 2000. T-to-C movement: causes and consequences. Ms., MIT \& University of Massachusetts.

Platzack, Christer \& Anders Holmberg. 1989. The role of AGR and finiteness in Germanic VO languages. Working Papers in Scandinavian Syntax 43, 51-76.

Rizzi, Luigi. 1996. Residual verb second and the Wh-criterion. In Adriana Belletti \& Luigi Rizzi (eds.), Parameters and Functional Heads. Oxford: Oxford University Press, 63-90.

Rizzi, Luigi. 1997. The fine structure of the left periphery. Liliane Haegeman (ed.), Elements of Grammar: Handbook in Generative Syntax. Dordrecht: Kluwer, 281-337.

Roberts, Ian. 1993. Verbs and Diachronic Syntax: A Comparative History of English and French. Dordrecht: Kluwer.

Roberts, Ian. 1996. Remarks on the Old English C-system and the diachrony of V2. In Ellen Brandner \& Gisella Ferraresi (eds.), Language Change and Generative Grammar. Opladen: Westdeutscher Verlag, 154-167. 
Roberts, Ian. 1998. Have/be raising, Move F, and Procrastinate. Linguistic Inquiry 29.1, $113-125$.

Roberts, Ian \& Anna Roussou. 2001. The EPP as a condition on the Tense dependency. In Svenonius (ed.), 125-155.

Sapir, Edward. 1921. Language. New York: Harcourt, Brace and World.

Rohrbacher, Bernhard. 1999. Morphology-Driven Syntax: A theory of V to I Raising and pro-drop. Amsterdam: John Benjamins.

Schütze, Carson. 1994. Serbo-Croatian second position clitic placement and the phonology-syntax interface. In Andrew Carnie, Heidi Harley \& Tony Bures (eds.), Papers on Phonology and Morphology (MIT Working Papers in Linguistics 21). Cambridge, MA: MIT, 373-473.

Svenonius, Peter (ed.). 2001. Subjects, Expletives, and the EPP. Oxford: Oxford University Press.

Swan, Toril. 1994. Old English and Old Norse initial adverbials and word order. In Toril Swan, Endre Mørck \& Olaf Janse Westvik (eds.), Language Change and Language Structure: Older Germanic Languages in Comparative Perspective. Berlin: Mouton de Gruyter, 233-270.

Thráinsson, Höskuldur. 1997. The chapters by Kiparsky, Roberts and Weerman: an epilogue. In van Kemenade \& Vincent (eds.), 495-508.

Tomaselli, Alessandra. 1995. Cases of verb third in Old High German. In Battye \& Roberts (eds.), 345-369.

Travis, Lisa. 1984. Parameters and Effects of Word Order Variation. Ph.D. dissertation, MIT.

Wackernagel, Jakob. 1892. Über ein Gesetz der indogermanischen Wortstellung. Indogermanische Forschungen 1, 333-436.

Warner, Anthony. 1997. The structure of parametric change, and V-movement in the history of English. In van Kemenade \& Vincent (eds.), 380-393.

Wright, Joseph. 1924. Grammar of the Gothic Language and the Gospel of St. Mark, Selections from the Other Gospels and the Second Epistle to Timothy. Oxford: The Clarendon Press.

Wurff, Wim van der. 1990. Diffusion and Reanalysis. Ph.D. dissertation, University of Amsterdam.

Zec, Draga \& Sharon Inkelas. 1990. Prosodically constrained syntax. In: Sharon Inkelas \& Draga Zec (eds.), The Phonology-Syntax Connection. Chicago: University of Chicago Press, 365-378.

Zeller, Jochen. 1994. Die Syntax des Tempus. Opladen: Westdeutscher Verlag.

\section{Electronic corpora}

Gippert, Jost. TITUS (Thesaurus Indogermanischer Text- und Sprachmaterialien). University of Frankfurt. http://titus.uni-frankfurt.de/

Kroch, Anthony \& Ann Taylor. 2000. The Penn-Helsinki Parsed Corpus of Middle English, Second Edition (PPCME2). Philadelphia: Department of Linguistics, University of Pennsylvania.

Taylor, Anne, Anthony Warner, Susan Pintzuk \& Frank Beths. 2002. The York-TorontoHelsinki Parsed Corpus of Old English (York Corpus). 